\title{
COMMENTS
}

\section{RESOLVING TREATY TERMINATION DISPUTES}

\section{INTRODUCTION}

\section{A. Goldwater ข. Carter}

In December 1978, President Carter announced that the United States intended to terminate unilaterally the Mutual Defense Treaty ${ }^{1}$ between the Republic of China (Taiwan) and the United States. ${ }^{2}$ The treaty committed both nations to the further development of defensive capabilities ${ }^{3}$ and to responding, in accordance with their respective constitutional processes, to armed attacks against the other party. 4 The presidential decision was pursuant to a treaty provision allowing termination of the agreement by either party on one year's notice. ${ }^{5}$

The President, however, did not seek or receive the approval of either the Senate or the Congress in terminating the treaty. ${ }^{\circ}$ As a result, members of both the Senate and the House of Representatives sought declaratory and injunctive relief in federal district court. 7 They argued that the President's termination of the Mutual Defense Treaty, without any congressional concurrence, unconstitutionally infringed upon the powers of the legislature. ${ }^{8}$ The plaintiffs in the case, Goldwater $v$. Carter, prevailed at the district court level. After holding that current members of Congress had stand-

1 Mutual Defense Treaty Between the United States of America and the Republic of China, Dec. 2, 1954, 6 U.S.T. 433, T.I.A.S. No. 3178 [hereinafter cited as Mutual Defense Treaty].

2 Diplomatic Relations Between the United States and the People's Republic of China, 1978 PUB. Papers 2264, 2266 (Dec. 15, 1978). See Note, Unilateral Termination of the 1954 Mutual Defense Treaty Between the United States and the Republic of China Pursuant to the President's Foreign Relations Power, 12 Vand. J. Transnat'L L. 133, I33-35 \& n.3 (1979) [hereinafter cited as Vand. Note].

${ }^{3}$ Mutual Defense Treaty, supra note 1, art. II.

4 Id. art. V.

5 Id. art. $\mathrm{X}$.

6 For a detailed discussion of the events leading to the termination, see Scheffer, The Law of Treaty Termination as Applied to the United States DeRecognition of the Republic of China, 19 Harv. INT'x L.J. 931, 931-41 (1978). See notes 174-77 infra \& accompanying text.

7 Goldwater v. Carter, 481 F. Supp. 949 (D.D.C.), rev'd per curiam, 617 F.2d 697 (D.C. Cir.) (en banc), vacated and remanded with directions to dismiss, 444 U.S. 996 (1979).

$8 \mathrm{Id} .950$. 
ing to assert these claims, ${ }^{9}$ and that the political question doctrine did not bar adjudication, ${ }^{10}$ Judge Gasch enjoined the State Department from implementing the President's notice of termination until the approval of either two-thirds of the Senate or a majority of both houses of Congress was obtained.11

On appeal, the U.S. Court of Appeals for the District of Columbia reversed. ${ }^{12}$ The majority accepted the lower court's decision on the issue of standing and on the political question doctrine, but held that the "constitutional allocation of governmental power" between the executive and the legislative branches did not require that prior legislative consent be obtained in order for the President to terminate the Mutual Defense Treaty. ${ }^{13}$

In a summary proceeding without oral argument, the Supreme Court vacated the circuit court judgment and remanded the case with directions to dismiss the complaint. ${ }^{14}$ Justice Rehnquist, joined by three other members of the Court, stated that the dispute presented a nonjusticiable political question. ${ }^{15}$ Two Justices expressly rejected this position, ${ }^{16}$ while three others did not address the issue. ${ }^{17}$

Neither the Goldwater litigation nor the events preceding it settled the fundamental question of which governmental branch or combination of branches may terminate treaties. Should the position taken in Justice Rehnquist's plurality statement be rejected, ${ }^{18}$ the constitutional aspects of treaty termination would be adjudi-

9 Id. $951-56$.

10 Id. 956-58.

11 Id. 965.

12 Goldwater v. Carter, 617 F.2d 697 (D.C. Cir.) (en banc) (per curiam), vacated and remanded with directions to dismiss, 444 U.S. 996 (1979).

13 Id. 709.

14 Goldwater v. Carter, 444 U.S. 996 (1979).

15 Chief Justice Burger and Justices Stewart and Stevens joined Justice Rehnquist's statement. Id. 1002-06.

16 Justice Powell, arguing for dismissal of the complaint as not ripe for judicial review, rejected the plurality's application of the political question doctrine. Id. 997-1002. Justice Brennan, dissenting, argued for affirmance of the circuit court's judgment. He contended that the President's unilateral termination of the Mutual Defense Treaty was supported by the executive"s "well-established authority to recognize, and withdraw recognition from, foreign governments." Id. 1006. Justice Brennan flatly rejected the plurality's interpretation of the political question doctrine. Id. 1006-07.

17 Justice Marshall, concurring in the result, filed no statement. Id. 996. Justices Blackmum and White, dissenting in part, argued that the Court should hear oral argument and give the case plenary consideration. Id. 1006.

18 Presently, the Rehnquist position is only one vote short of a majority. The composition of the court may change, however, or all three Justices who failed to reach the issue may reject such an application of the political question doctrine. See notes $15-17$ supra \& accompanying text. 
cated in the courts. Even if the Rehnquist position prevails, however, and the judiciary is barred from passing upon the constitutionality of various methods of terminating treaties, the constitutional issues raised by such terminations would continue to be of great importance. Each President is sworn to execute his office faithfully and to preserve the Constitution. ${ }^{19}$ This oath, as well as the chief executive's ultimate accountability to the American people, and the threat of impeachment, ${ }^{20}$ ensures that constitutional issues will be important in future treaty terminations. ${ }^{21}$

10 U.S. ConsT. art. II, $\S 1$, cl. 7. The President is also required to "take Care that the Laws be faithfully executed." Id. art. II, §3. See I. HENKIN, FOREIGN AfFairs and the Constitution 38-39 \& n.3 (1972) ("Presidents, finally, take a solemn oath to execute their office faithfully and to preserve the Constitution ...., and all of them have undoubtedly taken that oath seriously.").

20 The President is elected by the nation as a whole and is subject to impeachment and removal from office by the Congress. See U.S. CoNST. art. II, $\$ 4$ (removal of President after impeachment by House and conviction by Senate).

21 It can be argued that President Carter's successful unilateral termination of the Mutual Defense Treaty provides strong support for a plenary executive treaty termination power. Past practice has played an extremely important role in allocating governmental power between the legislature and the executive. See, e.g., Corwin, Judicial Review in Action, 74 U. PA. L. REv. 639, 658-59 (1926) (advancing theory of "adaptive interpretation"); McDougal \& Lans, Treaties and Congressional-Executive or Presidential Agreements: Interchangeable Instruments of National Policy, 54 YaLE L.J. 181, 186-88, 291 (1945) ("the continuance of [a] practice by successive administrations throughout our history makes its contemporary constitutionality unquestionable"); Monaghan, Presidential War-Making, 50 B.U. L. REv. 19, 21-25 (Spring 1970, Special Issue); Rostow, Great Cases Make Bad Law: The War Powers Act, 50 TEx. L. Rev. 833, 841-43 (1972). But see Berger, War-Making by the President, 121 U. PA. L. Rev. 29, 49-58 (1972) (criticizing those who suggest that "usurpation of power by the President, if repeated often enough, is legitimized"). In the words of Chief Justice John Marshall, the "constitution [is] intended to endure for ages to come, and, consequently, to be adapted to the various crises of human affairs." McCulloch v. Maryland, 17 U.S. ( 4 Wheat.) 316,415 (1819); cf. Youngstown Sheet \& Tube Co. v. Sawyer, 343 U.S. 579, 610-11 (1952) (Frankfurter, J., concurring) ("In short, a systematic, unbroken, executive practice, long pursued to the lnowledge of the Congress and never before questioned ... may be treated as a gloss on "executive Power' vested in the President by $\$ 1$ of Art. II."). But see Jorrs Marshall's Defense of McCulloch v. Maryland 18-21 (G. Gunther ed. 1969), in which Professor Gunther argues persuasively that later statements made by Marshall suggest that his language in McCulloch does not support wholesale "adaptation" of the Constitution to practical exigencies.

A single treaty termination by a President, however, does not amount to a past "practice." This is particularly true when, as in the Taiwan treaty dispute, the legislature vigorously opposes the executive's actions. In addition to the Goldwater case brought by individual senators and representatives, the Senate voted 59 to 35 to adopt a resolution providing: "That it is the sense of the Senate that approval of the United States Senate is required to terminate any mutual defense treaty between the United States and another nation." S. Res. 15, 96th Cong., 1st Sess., 125 Cong. Rec. S7015, S7038-7039 (daily ed. June 6, 1979).

There is also little unambiguous historical evidence of a plenary executive power over treaty terminations. The State Department argued that twelve past treaty terminations were "effected by the President without Congressional or Senate action." President's Power to Give Notice of Termination of US-ROC Mutual Defense Treaty, Memorandum for the Secretary of State from Herbert J. Hansell, the 


\section{B. Prior Analysis of Treaty Terminations}

Despite a considerable volume of literature, ${ }^{22}$ the treaty termination issue has resisted the analytical efforts of both courts and legal scholars. The vast majority of commentators share a common and, this Comment contends, faulty analytical approach. Despite obvious and important differences among treaties, ${ }^{23}$ the treaty termination power has been regarded as applicable in the same manner to all treaties. Once it is determined which governmental branch,

Legal Adviser (Dec. 15, 1978) (with attached appendix "History of Treaty Terminations by the United States") [hereinafter cited as Legal Adviser's Memorandum], reprinted in Treaty Termination: Hearings Before the Senate Comm. on Foreign Relations on S. Res. 15, 96th Cong., 1st Sess. 147-91 (1979) thereinafter cited as Treaty Termination Hearings]. Convincing rebuttals have been made, however, pointing to the presence of legislative involvement in many of these situations. See Scheffer, supra note 6, at 979-86. Thus, the historical support for a unilateral presidential treaty termination power is both limited and ambiguous.

In sum, although President Carter's unilateral termination of the Mutual Defense Treaty with Taiwan might play a role in the development of a governmental practice, there is little evidence that such a practice currently exists. The treaty termination question remains open, and undoubtedly will be the subject of future debate and controversy. Cf. Note, The Constitutional Twilight Zone of Treaty Termination: Goldwater v. Carter, 20 VA. J. INr'x L. 147, 168-69 (1979) ("the breadth of the President's foreign affairs power and the question of his authority to terminate U.S. treaty obligations remain unresolved and ripe for future conflict") [hereinafter cited as VA. Note].

22 See, e.g., E. Corwin, The President's Control of Foretgn Relations 109-16 (1917); $14 \mathrm{M}$. WhITEMAN, Digest OF INTERnational LAw 460-62 (1970); Berger, The President's Unilateral Termination of the Taiwan Treaty, 75 Nw. U. L. REv. 577 (1980); Bestor, Respective Roles of Senate and President in the Making and Abrogation of Treaties-The Original Intent of the Framers of the Constitution Historically Examined, 55 WAsE. L. REv. 1 (1979); Emerson, The Legislative Role in Treaty Abrogation, 5 J. LEGs. 46 (1978), reprinted in Treaty Termination Hearings, supra note 21, at 448; Goldwater, Treaty Termination is a Shared Power, 65 A.B.A.J. 198 (1979); Henkin, Litigating the President's Power to Terminate Treaties, 73 AM. J. INT'x L. 647 (1979); Kennedy, Normal Relations with China: Good Law, Good Policy, 65 A.B.A.J. 194 (1979); Nelson, The Termination of Treaties and Executive Agreements by the United States: Theory and Practice, 42 MinN. L. Rev. 879 (1958); Riggs, Termination of Treaties by the Executive Without Congressional Approval: The Case of the Warsaw Convention, 32 J. ArR L. \& CoM. 526 (1966); Scheffer, supra note 6; Note, Treaty Termination and the Separation of Powers: The Constitutional Controversy Continues in Goldwater v. Carter, 100 S. Ct. 533 (1979) (Mem.), 9 DEN. J. INT'L L. \& PoL'Y 239 (1980); Note, The President's Power to Terminate Treaties: The Unanswered Question of Goldwater v. Carter, 14 J. INT'L L. \& Econ. 301 (1980) [hereinafter cited as GWU Note]; Note, Unilateral Presidential Treaty Termination Power by Default: An Analysis of Goldwater v. Carter, 444 U.S. 996 (1979), 15 TEx. INT'L L.J. 317 (1980); VA. Note, supra note 21; VAND. Note, supra note 2; Reisman \& McDougal, Who Can Terminate Mutual Defense Treaties?, NAr'L L.J., May 21, 1979, at 19, col. 1 (first of two parts) [hereinafter cited as Reisman \& McDougal I]; Reisman \& McDougal, Can the President Unilaterally End Treaties?, NAT'L L.J., May 28, 1979, at 17, col. 1 (second of two parts) [hereinafter cited as Reisman \& McDougal II].

23 See note 31 infra \& accompanying text. 
or combination of branches, ought to possess the power to terminate treaties, further inquiry ceases-that branch or combination of branches may terminate all treaties.24 No systematic attempt has been made to determine whether different treaties require different methods of termination. ${ }^{25}$

The position of the executive branch in the Taiwan treaty dispute was that the President acting alone could terminate any treaty. ${ }^{28}$ Advocates of this position have stressed the "international"

24 E.g., E. Conwin, supra note 22, at 115 ("the power of terminating the international compacts to which the United States is party belongs... . to Congress alone"); Henkin, supra note 22, at 651-54 (the President has sole authority to terminate treaties); Kennedy, supra note 22, at 196; Reisman \& McDougal II, supra note 22, at 17, col. 4 ("[T]he fundamental principles of a democratic sharing of power, and of checks and balances to protect that sharing, require that Congress be accorded a role in the termination of all agreements, whatever the modality of their making, other than purely presidential agreements."). Cf. Goldwater v. Carter, 617 F.2d 697, 707 (D.C. Cir. 1979) ("We cannot find an implied role in the Constitution for the Senate in treaty termination for some but not all treaties in terms of their relative importance. There is no judicially ascertainable and manageable method of making any distinction among treaties on the basis of their substance, the magnitude of the risk involved, the degree of controversy which their termination would engender, or by any other standards."). But cf. id. ("All we decide today is that two-thirds Senate consent or majority consent in both houses is not necessary to terminate this treaty in the circumstances before us now.").

25 The unwillingness of prior commentators to consider the possibility that different treaties should be terminated differently is exemplified by the debate between Professors Henkin and Berger. Replying to Henkin's arguments, see Henkin, supra note 22, at 651-54, for an exclusive presidential power to terminate treaties, Berger wrote:

Consequently, I cannot agree with Professor Henkin that "termination of a treaty by the President ... is an international act terminating an international legal obligation of the United States." ... .

Professor Henkin's view that "many a treaty is not domestic law at all, in that it has no domestic legal implications," can be countered by run-ofmine examples to the contrary. Reciprocal tariff agreements self-evidently have domestic implications. So too have extradition treaties and treaties guaranteeing the safety of embassy personnel.

Berger, supra note 22 , at $600 \mathrm{n} .164$ (emphasis in original) (citations omitted). Plainly, both Berger and Henkin are correct, as far as they go. No doubt treaty termination involves abrogation of an "international legal obligation." See text accompanying notes 34-36 infra. Yet, as Berger points out, numerous examples of treaties with "domestic legal implications" can be produced. This Comment attempts to reconcile these two observations, by distinguishing among treaties. Thus, the proper method of terminating a treaty will depend upon the particular domestic and international implications of termination. For a brief suggestion, similar to the approach taken in this Comment, that treaty termination disputes be resolved on a case-by-case basis, see Treaty Termination Hearings, supra note 21, at 355 (prepared statement of Herbert Brownell).

${ }^{26}$ E.g., Points and Authorities in Support of Defendants' Motion to Dismiss or, in the Alternative, for Summary Judgment at 2438 , Goldwater v. Carter, 481 F. Supp. 949 (D.D.C. 1979), reprinted in Treaty Termination Hearings, supra note 21, at 91, 121-35 ("it is for the President, under Article II, to . . . terminate treaties") (emphasis added); Legal Adviser's Memorandum, stupra note 21, at 1 , reprinted in Treaty Termination Hearings, supra note 21, at 147 (affirming President's power to terminate treaties acting alone). 
aspects of treaty termination, ${ }^{27}$ and have relied heavily upon the President's "foreign affairs" power. ${ }^{28}$ In response, proponents of legislative powers have argued that some sort of legislative participation is constitutionally required in all treaty terminations. ${ }^{29}$ This position emphasizes the status of treaties as the "supreme Law of the Land," and concludes that the termination of a treaty constitutes a repeal of domestic law-an act beyond the constitutional powers of the executive. ${ }^{30}$

This Comment begins by arguing that different treaties may require different termination processes. The United States is party to a wide variety of treaties, ${ }^{31}$ each of which is a unique legal instrument with unique legal consequences. ${ }^{32}$ The extraordinary diversity in the subject matter and the legal consequences of existing treaties suggests that different treaty terminations will implicate different governmental interests and political concerns. Thus, a termination procedure that satisfactorily responds to the interests raised in one context may be an inadequate response to different concerns arising from the termination of a different treaty. After isolating the more significant governmental interests that may be implicated by the termination of a treaty, the Comment proposes a

27 See, e.g., Henkin, supra note 22, at 652 ("Termination of a treaty is an international act, and the President, and only the President, acts for the United States in foreign affairs."); Kennedy, supra note 22, at 195-96; GWU Note, supra note 22 , at 319 .

28 See, e.g., Goldwater v. Carter, 617 F.2d 697, 704-07 (D.C. Cir. 1979) ("In short, the determination of the conduct of the United States in regard to treaties is an instance of what has broadly been called the 'foreign affairs power' of the President."). See notes 37-64 infra \& accompanying text.

29 See, e.g., Berger, supra note 22, at 622 (arguing for some sort of legislative participation in all treaty terminations); Goldwater, supra note 22; Reisman \& McDougall I \& II, supra note 22.

30 Goldwater, supra note 22, at 198-99; Reisman \& McDougal I, supra note 22, at 19 , col. 3. Cf. Goldwater v. Carter, 481 F. Supp. 949, 962 (D.D.C. 1979) ("Termination of a treaty also involves a repeal of the "law of the land" established by the agreement.").

31 Compare Agreement on the Conservation of Polar Bears, Nov. 15, 1973, 27 U.S.T. 3918, T.I.A.S. No. 8409 and North Atlantic Treaty, Apr. 4, 1949, 63 Stat. 2241, T.I.A.S. No. 1964, 34 U.N.T.S. 243 and Convention for the Protection of Producers of Phonograms Against Unauthorized Duplication of Their Phonograms, Oct. 29, 1971, 25 U.S.T. 309, T.I.A.S. No. 7808. See generally U.S. Dep'T of State, Treaties in Force (1980).

32 See N. Leech, C. Olrver \& J. Sweeney, The International Legal System 929 (1973) ("Like contracts or trusts in private law, international agreements are cut to the cloth of the interests of the parties.") [hereinafter cited as N. LEECH]; $i d$. 931 ("every treaty constitutes obligations and rights that, prior to the conclusion of the treaty, had not yet existed, obligations and rights which come into existence by the treaty") (quoting $\mathrm{H}$. Kexsen \& R. Tucker, Prunclples of INTERNATIONAL LAW 456 (2d ed. 1966)). See text accompanying notes 33-36 and 74-75 infra. 
balancing test designed to assess the strength of these interests in particular situations.

The Comment concludes by arguing that because of the unsettled nature of separation of powers doctrine, it often will be difficult to obtain clear-cut answers to the question who may terminate a treaty. Consequently, many of the substantive conclusions that are reached-by the proposed balancing test or otherwise-will be open to considerable dispute. It is thus particularly important that a meaningful and accepted procedure for making this decision be developed. A process encouraging consultation, discussion, and perhaps compromise between the executive and legislative branches will help to ensure that many termination disputes never arise or are quickly settled. This Comment proposes one possible procedure.

\section{Governmental INTERests Implicated By Treaty Termination}

This section examines four aspects of treaty termination-first, the international legal effects of a treaty termination; second, the domestic legal effects of a treaty termination; third, the subject matter of the treaty; and fourth, the "fundamentalness" or importance of the treaty to American foreign policy. It is argued that each of these aspects gives rise to competing executive and legislative interests in making treaty termination decisions.

\section{A. International Effects of Treaty Termination and Presidential Interests}

The making of a treaty has a number of legal consequences in both international and domestic law. ${ }^{33}$ Chief among these are the international rights and obligations created by a treaty. Nations party to an agreement are bound to fulfill these obligations in good faith. ${ }^{34}$ Because of these obligations, a treaty termination has two

33 "For clarity of analysis, it is thus well to distinguish between treaty-making as an international act and the consequences which flow domestically from such act." Goldwater v. Carter, 617 F.2d 697, 705 (D.C. Cir.) (en banc) (per curiam), vacated and remanded with directions to dismiss, 444 U.S. 996 (1979); L. HENkTN, supra note 19, at 129-71; VA. Note, supra note 21, at 161 . See note 32 supra \& accompanying text.

34 The international obligation created by an international agreement is subject to the rule of customary international law, pacta sunt servanda, requiring that treaty obligations be fulfilled in good faith by parties to the agreement. H. KreseN \& R. TUCKER, supra note 32 , at 456 , seprinted in $\mathrm{N}$. LEECH, supra note 32 , at 931 . This rule of customary international law has been "codified" in the Vienna Convention on the Law of Treaties: "Every treaty in force is binding upon the parties to it and must be performed by them in good faith." Vienna Convention on the 
principal international consequences. First, termination of a treaty relieves a nation of potential liability in international law for failure to fulfill its agreement. ${ }^{35}$ Second, a treaty termination deprives a nation of the right to protest, or take other action, against former parties to the agreement for their failure to fulfill agreedupon courses of conduct. ${ }^{36}$

\section{The President's Foreign Affairs Power}

Any discussion of the governmental interests implicated by an alteration of the international legal rights and obligations of the United States must begin with the executive's "foreign affairs" power. $^{37}$ Although there is no longer any question that the national government possesses the constitutional power to engage in the conduct of foreign affairs, ${ }^{38}$ there is considerable dispute surrounding the allocation of that power between the legislative and executive branches. ${ }^{39}$ Professor Corwin has commented that the Constitution is "an invitation to struggle for the privilege of directing American foreign policy." ${ }^{40}$ The invitation has been accepted frequently; disputes between the President and the Congress over the control of foreign policy have been a recurrent feature of American political history. ${ }^{41}$ Notable examples include the de-

Law of Treaties, opened for signature May 23, 1969, art. 26, U.N. Doc. A/CONF. 39/27 (1969), reprinted in 63 AM. J. INT'L L. 875, 884 (1969).

35 Among other reactions, breach of an international agreement could result in diplomatic protest, see generally VI G. Hackworth, Drgest of International LAw 1-159 (1943), or the initiation of action before a multinational organization, such as the International Court of Justice, see $12 \mathrm{M}$. WHITEMAN, supra note 22, at $1153-471$.

36 See H. KELSEN \& R. TuCKeR, supra note 32 , at 456, reprinted in N. LEECH, supra note 32 , at 931 ("The statement that the treaty has binding force' means nothing but that the treaty is or creates a norm establishing obligations and rights of the contracting parties.").

37 See generally L. HENKI, supra note 19, at 37-65.

38 Id. 15-35.

39 Justice Jackson, concurring in Youngstown Sheet \& Tube Co. v. Sawyer, wrote that constitutional language and historical precedent are "almost as enigmatic as the dreams Joseph was called upon to interpret for Pharoah." 343 U.S. 579, 634 (1952). See E. CoRwIN, supra note 22; L. HeNsin, supra note 19, at 3I-35, 89-92; Q. Wright, Tae Control of AMierican Foreign Relatrons 3 (1922) ("There is no phase of American constitutional law on which commentators have found it more difficult to procure a logical and consistent theory than the control of foreign relations.").

40 E. Corwin, The President: Office and Powers 208 (3d ed. 1948).

41 For discussions suggesting that controversy over the control of foreign policy was frequent in the earliest days of the republic, see A. SOFAER, WAR, Foreign Aframs and Constitutional Power (1976) and Sofaer, The Presidency, War, and Foreign Affairs: Practice Under the Framers, 40 L. \& ContemP. Pros. 12 (Spring 1976). 
bates between "Pacificus" and "Helvidius" in the first days of the republic, ${ }^{42}$ the debate between Senators Spooner and Bacon over President Theodore Roosevelt's conduct of foreign affairs, ${ }^{43}$ the War Powers Resolution, ${ }^{44}$ and of course, the treaty termination dispute.

Although vigorously contested, these disputes generally have been resolved in favor of increased executive foreign affairs powers. ${ }^{45}$ The result, as commentators have recognized, has been the development of broad presidential authority over the conduct of foreign policy.8 In the words of Professor Henkin, "All will agree that by constitutional exegesis, by inferences and extrapolations small and large ... Presidents have achieved and legitimated an undisputed, extensive, predominant, sometimes exclusive 'foreign affairs power' . . . "47 A number of attempts by Congress in the last decade to assert control over the making of foreign policy ${ }^{48}$ may mark a slowing or reversal of this trend. ${ }^{49}$ Absent a truly radical

42 After President Washington's proclamation in 1793 of U.S. neutrality in hostilities between France and Britain, Alexander Hamilton, under the pseudonym "Pacificus," authored eight articles in defense of the President's action. Madison, writing under the name "Helvidius," responded with five pieces attacking the constitutionality of Washington's actions. See E. Corwn, supra note 22, at 7-32.

43 Id. 168-204.

44 Pub. L. No. 93-148, 87 Stat. 555 (codified at 50 U.S.C. $\$ \$ 1541-1548$ ) (H.R.J. Res. 542, adopted over a presidential veto on November 7, 1973). The War Powers Resolution specifically enumerates the circumstances in which deployment of U.S. military forces abroad is permitted, and purports to limit executive authority to so employ the armed forces. See L. Trmbe, AMrerican Constriutional LAw 176-78 (1978); Rostow, supra note 21, See also Casper, Constitutional Constrainis on the Conduct of Foreign and Defense Policy: A Nonjudicial Model, 43 U. CFr. L. Rev. 463 (1976).

45 See, e.g., A. Sofaer, supra note 41; Patterson, The Rise of Presidential Power Before World War II, 40 L. \& Contenc. ProB. 39 (Spring 1976).

$46 \mathrm{E}$. Conwnv, supra note 22, at 207 ("On the whole, therefore, the net result of a century and a quarter of contest for power and influence in determining the international destinies of the country remains decisively and conspicuously in favor of the President."); L. Trune, supra note 44, at 163 ("In the area of foreign affairs, however, there is wide agreement at least that the President is invested with great power."); Q. Wriger, supra note 39, at 140 ("those favoring the executive prerogative have the better of the argument," but advancing theory of a fourth governmental department to control foreign policy); King \& Leavens, Curbing the Dog of War: The War Powers Resolution, 18 Harv. INT'x L.J. 55, 61-62 (1977); Monaghan, supra note 21, at 23-25. Cf. I. Destler, Presidents, Bureaucrats, AND FOREIGN POLTCY (1972) (proposing institutional changes for achieving more centralized conduct of foreign policy).

47 L. HeNsIN, supra note 19, at 44.

48 The 1970s were marked by a number of congressional efforts to reclaim a voice in the formulation of foreign policy. Notable examples of the new mood of legislative assertiveness include cutting off funds for the bombing of Cambodia, the War Powers Resolution, and the debates surrounding the Panama Canal treaties. See T. Franck \& E. Weisband, Foreign Polycy by Congress (1979).

49 Professors Franck and Weisband forcefully make this argument. Id. 3.

While recognizing that increased legislatlve initiatives in the field of foreign affairs have led to "circus-like aspects of the Congressional debates on Panama[,] 
restructuring of American government, however, expansive presidential power over foreign affairs seems likely to continue..$^{50}$

The rise of presidential power occurred with little obvious support from the text of the Constitution. The Framers, while generously supplying Congress with express grants of powers relating to the conduct of foreign affairs, ${ }^{51}$ provided the executive with little in the way of specific foreign affairs powers. ${ }^{52}$ Nonetheless, proponents of expansive presidential powers have formulated a number of theories justifying the President's claims to power over foreign policy. ${ }^{53}$ The acceptance of one such formulation by the

- . idiosyncratic subcommittee chairmen, self-aggrandizing staffers, incomprehensible requirements for Executive reporting to Congress, and dense jungles of legislation with impenetrable tangles of standards, roamed by monstrous subordinate clauses," id. 8, Franck and Weisband generally approve of the "revolution" in foreign policy-making. Conceding that "[t]he legislative branch has yet to build a convincing delivery system or to win its battle of the attention span," id. 9, Franck and Weisband conclude that, after Watergate and Vietnam, a broad presidential foreign affairs power is a risk that can no longer be taken. Id. 293.

For further discussion of congressional efforts to win a voice in the making of foreign policy, see Balmer, The Use of Conditions in Foreign Relations Legislation, 7 DEN. J. INT'L L. \& Pot'y 197 (1978); Sparkman, Checks and Balances in American Foreign Policy, 52 IND. L.J. 433 (1977).

50 President Carter's handling of the Taiwan treaty termination and the Iranian hostage crisis indicate that, despite recent congressional assertiveness, executive preeminence in the area of foreign policy is unlikely to be easily shaken. Accord, Allison, Making War: The President and Congress, 40 L. \& Contrmp. ProB. 86, 105 (Summer 1976).

51 See note 125 infra; L. HeNkn, supra note 19, at 37.

$52 I d$. ("A stranger reading the Constitution would get little inkling of such large Presidential authority, for the powers explicitly vested in him are few and seem modest, far fewer and more modest than those bestowed upon Congress.").

53 These theories have been discussed extensively elsewhere and are only summarized here.

(1) Alexander Hamilton argued that the Constitution's grant of “The Executive Power" to the President provided him with a variety of inherent powers, including broad authority in the field of foreign affairs. E. CoRwT, supra note 22, at 8-15 (quoting Hamilton's article of June 29, 1793, under the pseudonym Pacificus).

(2) Justice Sutherland theorized that the power to conduct foreign relations is inherent in the notion of national sovereignty. The President may wield this inherent power largely free of the ordinarily applicable checks and balances of the Constitution. United States v. Curtiss-Wright Export Corp., 299 U.S. 304, 317-22 (1936).

(3) Successive Presidents have claimed broad undefined authority to protect the interests of the nation. See T. Rooseveit, AN AutoBIocraphY 371-72 (1914), quoted in L. HENkTN, supra note 19, at 39-40; R. Nixon, A NEw RoAD For AMERrCA 675 (1972) (claiming "the right of the President of the United States under the Constitution to protect the lives of American men").

(4) Commentators, through liberal interpretation of the Constitution's express grants of power to the President, have found textual support for a broad executive foreign affairs power. See, e.g., L. HENKIn, supra note 19, at 41-42. 
Supreme Court, in United States v. Curtiss-Wright Export Corp., ${ }^{54}$ indicates the appeal exercised by broad claims of executive power. The Curtiss-Wright Court described the executive's authority as "the very delicate, plenary and exclusive power of the President as the sole organ of the federal government in the field of international relations." 85 This sweeping dictum is plainly overbroad, ${ }^{\text {b8 }}$ and has generated considerable controversy. ${ }^{57}$ It nevertheless lends support to claims of expansive presidential power over foreign policy-making.

Executive claims to broad foreign affairs powers are supported by several other arguments. It was pointed out in The Federalist that both the conduct and the policy-making of foreign affairs require characteristics uniquely possessed by the executive branch ${ }^{58}$

(5) The Constitution is to be interpreted in light of evolving governmental practices. This "gloss of life" uses the extensive authority actually exercised by the executive as theoretical justification for presidential powers. See note 21 supra.

For additional discussion of theoretical justifications for an expansive executive foreign affairs power, see L. HENKan, supra note 19, at 15-65 and Van Alstyne, The Role of Congress in Determining Incidental Powers of the President and of the Federal Courts: A Comment on the Horizontal Effect of the Sweeping Clause, 40 I. \& Contemp. Prob. 102, 132-33 (Spring 1976).

54299 U.S. 304 (1936).

65 Id. 320. This language is frequently cited. E.g., L. Trire, supra note 44, at 164; Henkin, supra note 22, at 652; VA. Note, supra note 21, at 153.

Curtiss-Wright echoed John Marshall's classic statement: "The President is the sole organ of the nation in its external relations, and its sole representative with foreign nations." 299 U.S. at 319 (quoting 10 ANNAIS OF CoNG. 613 (1800)).

56 Compare

When the Supreme Court addressed the question in Curtiss-Wright, it recognized the "very delicate, plenary and exclusive power of the President as the sole organ of the federal government in the field of international relations .... A power so characterized, I believe, implies the authority to make the kind of decision that has to be made for the United States when a treaty no longer serves our interests ....

Henkin, supra note 22, at 652 (footnote omitted) with

Such conclusion [that the President may unilaterally terminate a treaty] cannot rationally be derived from the notion of the president as the principal "organ" of our country in external affairs; that function, historically, has been exhausted in the conduct of negotiations and in the utterances and notices of ratification and termination. Such a conclusion would corrupt the built-in safeguards in our check-and-balance system.

Reisman \& McDougal I, supra note 22, at 19, col. 3.

57 See, e.g., L. HENEx, supra note 19, at 45 ("It is not apparent that either 'foreign affairs power' or 'sole organ' [in the Curtiss-Wright and John Marshall characterizations, respectively] aspires to legal precision ....").

68 Alexander Hamilton described the strengths of the executive branch in the field of foreign affairs as follows: "Accurate and comprehensive knowledge of foreign politics; a steady and systematic adherence to the same views; a nice and uniform sensibility to national character; decision, SECRECY, and despatch . . . ." 
-the ability to act quickly, to provide coherent, centralized decisionmaking and planning, to maintain secrecy, and to gather and assimilate information. Similarly, the President has unique incentives to act in the interest of the nation as a whole.59 The executive's particular competence in the conduct of foreign affairs can be contrasted with the many disadvantages the legislature faces in the field. Numerous commentators arguing for a broad executive foreign affairs power have pointed to the "glacial legislative process," the "excessively parochial" orientation of most legislators, the "decentralized legislative decision-making process," and the inability of the legislature to formulate and execute long-range foreign policy. ${ }^{60}$

Some commentators, particularly prior to the Vietnam era, vigorously urged that executive institutional competence in the area of foreign affairs requires a restructuring of the division of power over the making of foreign policy. ${ }^{61}$ Thus, J. William Fulbright wrote:

The Federauist No. 75 (A. Hamilton), at 83 (Bourne ed. 1901) [hereinafter cited as THE FEDERALIST]. Indeed, even vigorous opponents of a broad executive foreign affairs power have recognized that the executive branch possesses inherent advantages in the field of foreign relations. See note 64 infra \& accompanying text.

For a comprehensive treatment of the institutional strengths and weaknesses of the executive branch in foreign affairs, see I. DESTLER, supra note 46.

59 The President, unlike members of Congress, is elected by the nation as a whole. Similarly, the President is held responsible by the public for the well-being of the nation. See C. Rossiter, The Presidency: Focus of Leadership in Perspectrves on the Presidency 35 (S. Bach \& G. Sulzner eds. 1974).

${ }^{60}$ See note 58 supra and note 62 infra. Professor Henkin has observed that "the President's control of international communication and of the daily conduct of foreign relations has made it difficult, perhaps impossible, for Congress to exercise its constitutional powers and responsibilities effectively, "separately." " Henkin, "A More Effective System" for Foreign Relations: The Constitutional Framework, 61 VA. L. REv. 751, 765 (1975) (emphasis omitted). Henkin also argued that members of Congress frequently lack the information, understanding, and interest needed to make intelligent foreign policy judgments, and attacked the "maddening inefficiency of a two-tier authorization and appropriation process." Id. 768. Others have pointed to more recent developments, including the "progressive dilution of party discipline," the "[d]ecline in the authority of congressional leaders," and the disruptive effect of the existing committee system. Manning, The Congress, the Executive and Intermestic Affairs: Three Proposals, 55 FonetGN Aff. 306, 311 (1977). See also R. Dafm, Congress and Foreign Policx 3 (1950) (The conclusion "is unavoidable that the national legislature . . is remarkably ill-suited to exercise a wise control over the nation's foreign policy."); Kurland, The Impotence of Reticence, 1968 Duke L.J. 619.

61 Citing the institutional superiority of the executive, many commentators have supported increased presidential authority over foreign policy. M. BunDY, The Strength of Government (1968); J. Burns, Presmential Government (1966); I. Destruer, supta note 46; W. Elliort, UnIted States Foreign Policy (1952); R. Neustadt, Presidential, Power: The Politics of Leadership (2d ed. 1976). See note 62 infra \& accompanying text. 
[T] ] Une United States is under the most pressing compulsion to form wise and farsighted policies, oriented to a clearly conceived concept of the national interest and implemented by carefully devised and firmly co-ordinated specific lines of action. ... The President alone can act to mobilize our power and resources toward the realization of clearly defined objectives .... ${ }^{22}$

Although this view is undoubtedly an extreme one, there is a consensus of sorts that the executive branch is institutionally more competent in the field of foreign policy than the legislature. ${ }^{63}$ Even the most ardent proponents of legislative powers concede that, "[c]ould we view the matter as an original question ... [legislative shortcomings] might persuade that exclusive power over foreign affairs is best lodged in the President." ${ }_{4}$ Taken together, the Curtiss-Wright dictum and the institutional strengths of the executive branch weigh heavily in favor of an expansive view of the President's foreign affairs power.

62 Fullbright, American Foreign Policy in the 20th Century Under an 18thCentury Constitution, 47 ConNell L.Q. 1, 12 (1961). Fulbright added, "The source of an effective foreign policy under our system is Presidential power." Id. 2.

Noting the post-Watergate assertiveness of Congress in foreign policy matters, Fulbright has since moderated his position. Fulbright, The Legislator as Educator, 57 FOREIGN AFF. 719 (1979). His apparent acceptance of expanded legislative participation in the making of foreign policy, however, is conditioned upon the creation of a "deliberative" legislature, whose members will abjure "political salesmanship," the espousal of special interests, and the acquisition of personal power. The likelihood of Congress ever fulfilling this conception is open to some question, and, as Fulbright notes, "without a commensurate demonstration of public responsibility [by Congress], there is much to be said for a revival of presidential leadership." Id. 727.

${ }^{63} \mathrm{~A}$ number of commentators, noting the strengths of the executive in the field of foreign policy, have argued for a liberal interpretation of presidential powers within the existing constitutional framework. See, e.g., Henkin, supra note 22, at 651-54; Monaghan, supra note 21 . See note 61 supra.

Several commentators, on the other hand, have questioned the institutional superiority of the executive in the field of foreign policy. See Berger, supra note 21; Casper, supra note 44; Katzenbach, Foreign Policy, Public Opinion and Secrecy, 52 FOREIGN AFF. I (1973). Invariably, such arguments focus on perceived executive errors in the handling of the Vietnam situation. One commentator has written: "The long-accepted assumption that Presidents and their experts alone possess the perspective and knowledge needed to define the national interest in a hostile world seems to have been discredited to a considerable extent by the Indochina war and Watergate." Casper, supra note 44, at 483 . See Berger, supra note 21 , at 83 . These arguments misconceive the claims of executive institutional superiority. By saying that the executive branch is better able to conduct coherent, consistent, and successful foreign policy, one promises no miracles. Rather, one tries to reduce the danger of mistakes. Vietnam was a tragic example of presidential failures. It is not, however, as some have suggested, "proof" that the executive branch is ill-suited to the conduct of foreign policy.

64 R. Berger, Executtve Prumlege 119 (1974). 


\section{The Presidential Interest in Treaty Termination}

These broad, if somewhat controversial, claims of presidential power are particularly strong when asserted in the specific context of a treaty termination dispute. As discussed, the termination of a treaty alters the nation's international legal obligations. ${ }^{65}$ The President traditionally has exercised extraordinary power over a wide variety of actions that have a similar effect on the nation's commitments in international law. ${ }^{68}$ For example, the executivehas exclusive control over the recognition of foreign states and governments, ${ }^{67}$ the negotiation of treaties, ${ }^{68}$ the making of (or refusal to make) treaties once Senate approval has been obtained, ${ }^{69}$ the initiation and settlement of claims for foreign reparations, ${ }^{70}$ the reception of foreign diplomats, ${ }^{71}$ and the proclamation of U.S. intentions in the area of foreign relations. ${ }^{22}$ This broad, yet accepted, authority over the nation's international legal rights and obligations suggests that the President should enjoy similar authority over analogous acts which alter the nation's legal duties through treaty termination.

An expansive view of the President's foreign affairs power lends further support to this presumption of executive prerogative. As discussed, the weight of both historical precedent and scholarly opinion, as well as the institutional competence of the presidency, suggest that the President should have a predominant role in the conduct of foreign relations. Accordingly, because of the international consequences of treaty terminations, there is strong support for substantial, and perhaps exclusive, executive control over the

65 See notes 34-36 supra \& accompanying text.

66 For a discussion of the importance of past practice in constitutional analysis, see note 21 supra.

67 United States v. Pink, 315 U.S. 203, 229-30 (1942); E. Conwn,, supra note 22, at 205-06; L. HENKon, supra note 19, at 93; L. TruBe, supra note 44, at $165 \& \mathbf{n . 7}$.

68 E. Conwin, supra note 22, at 206; L. HENkIN, supra note 19, at 130-31.

${ }^{69}$ S. Crandall, Treaties, Thetr Maktng and Enforcement (2d ed. 1916); L. HeNkJN, supta note 19, at 133 .

70 Pink, 315 U.S. at 240 (Frankfurter, J., concurring) ("That the President's control of foreign relations includes the settlement of claims is indisputable."). See also L. HenknN, supra note 19 , at 48 .

71 U.S. Const. art. II, $\$ 3$ (The President "shall receive Ambassadors and other public Ministers.”).

72 The doctrines and policies proclaimed by Presidents Monroe, Truman, Eisenhower, and Carter are dramatic examples of the exercise of this power. In the words of Professor Henkin, the President "acts and speaks the part of the United States in the mysterious process by which customary international law is formed." L. HENKIN, supra note 19, at 48 . 
termination of treaties. Whether any congressional interest in the termination of a treaty is sufficiently compelling to warrant a legislative role in such actions, ${ }^{73}$ and thus strong enough to limit the President's rightfully broad powers in this area, is the subject for the remainder of this section.

\section{B. Domestic Effects of Treaty Termination and Congressional Interests}

Sole reliance on the international effects of treaty termination and the executive's foreign affairs power fails to address important domestic effects of treaty termination. ${ }^{74}$ In constitutional terms, a treaty is the "supreme Law of the Land." 75 To a large extent, however, the presence of domestic effects is determined by whether or not the treaty is self-executing. The Supreme Court, in Foster v. Neilson, ${ }^{76}$ articulated the classic distinction between self-executing and non-self-executing treaties:

Our constitution declares a treaty to be the law of the land. It is, consequently, to be regarded in courts of justice as equivalent to an act of the legislature, whenever

73 Determining the precise type of legislative participation in treaty termination decision-making is problematic. Logical symmetry would suggest that two-thirds of the Senate approve all treaty terminations. The functional approach suggested in this Comment rejects this analysis, looking instead to the governmental interests implicated by particular treaty terminations. Taking this approach, two points support viewing the approval of a majority of each house as adequate legislative participation. First, this is closely tailored to the principal legislative interests at stake in treaty terminations-Congress's control over the law of the land and its participation in the formulation of foreign policy. See text accompanying notes $\mathbf{8 4}$ \& 124-25 infra. Second, the requirement of two-thirds Senate approval has been sharply criticized in the context of treaty making. See, e.g., McDougal \& Lans, supra note 21, passim; Oliver, Getting the Senators to Accept the Reference of Treaties to Both Houses for Approval by Simple Majorities, 74 Axr. J. INr'x L. 142 (1980). Accordingly, it would be unwise to extend the requirement to treaty terminations, particularly absent constitutional language so requiring. Accord Berger, supra note 22, at 620-22; Treaty Termination Hearings, supra note 21, at 308 (remarks of Professor Abram Chayes).

74 It is interesting to note that some commentators have focused primarily upon the domestic effects of treaty termination in arguing for legislative participation in treaty terminations. See, e.g., Goldwater, supra note 22, at I99; Reisman \& McDougal II, stpra note 22, at 17, col. 4. This approach, because it ignores the international aspects of treaty terminations, is also unsatisfactory. The better approach is one that integrates all the aspects of treaty terminationdomestic and international-and attempts to reconcile the various governmental interests and political concerns that these effects implicate.

75 U.S. CoNsT. art. VI, $\$ 2$ ("This Constitution, and the Laws of the United States which shall be made in Pursuance thereof; and all Treaties made, or which shall be made, under the Authority of the United States, shall be the supreme Law of the Land ....").

7627 U.S. (2 Pet.) 253 (1829), overruled on other grounds, United States v. Percheman, 32 U.S. (7 Pet.) 52, 89 (1833). 
it operates of itself without the aid of any legislative provision. But when the terms of the stipulation import a contract, when either of the parties engages to perform a particular act, the treaty addresses itself to the political, not the judicial department; and the legislature must execute the contract before it can become a rule for the Court. ${ }^{77}$

Important legal effects flow from this distinction between selfexecuting and non-self-executing treaties.

\section{Self-Executing Treaties}

When a treaty is self-executing, it creates domestic law identical to that of a federal statute. ${ }^{78}$ Immediately upon its entry into force, a self-executing treaty creates enforceable legal rights. ${ }^{79}$ It supercedes prior inconsistent federal statutes, ${ }^{80}$ preempts state laws and constitutional provisions, ${ }^{81}$ and is superceded by subsequent federal statutes. ${ }^{82}$ In short, not only does the Constitution classify self-executing treaties as the "Law of the Land," but many of the legal effects of such treaties are indistinguishable from those of federal statutes.

These characteristics of a self-executing treaty give rise to some doubt as to the constitutionality of an exclusive executive power to terminate such treaties. The Constitution, of course, does not indicate how a treaty should be terminated. It does, however, estab-

77 Id. 314. See also Edye v. Robertson (The Head Money Cases), 112 U.S. 580, 598-99 (1884).

The determination whether a treaty is self-executing or non-self-executing is a question concerning the intent of the parties. L. HENkrs, supra note 19, at 156-61.

78 Whitney v. Robertson, 124 U.S. 190, 194 (1888). See also Chae Chan Ping v. United States (The Chinese Exclusion Case), 130 U.S. 581 (1889).

${ }^{79} \mathrm{~L}$. Henkan, supra note 19, at 157-59. Henkin also notes that a treaty does not become enforceable as the law of the land until proclaimed. Id. 158, n.tf. See cases cited in note 78 supra.

80 The Chinese Exclusion Gase, 130 U.S. at 600; REsTatement (SECOND) OF THE FonEIGN RELATIONS LAW OF THE UNITED States $\$ 141$ (1) \& Reporters" Notes (1965) [hereinafter cited as RestatemenT]. See Whitney, 124 U.S. at 194. 81 Hauenstein v. Lynham, 100 U.S. 483 (1880) (state law disqualifying aliens from inheritance preempted by contrary treaty); Ware v. Hylton, 3 U.S. (3 Dall.) 199 (1796) (state law voided by Treaty of Peace between United States and Britain ); Restatement, supra note $80, \S 141$, Comment c.

82 The Head Money Cases, 112 U.S. at 599 ("[S]o far as a treaty made by the United States with any foreign nation can become the subject of judicial cognizance in the courts of this country, it is subject to such acts as Congress may pass for its enforcement, modification, or repeal."); The Cherokee Tobacco, 78 U.S. (II Wall.) 616 (1871); RESTATEMENT, supra note 80, $\$ 145$. Federal statutes which supersede a treaty as domestic law do not affect the international obligations of the United States. Id. $\$ 145(2)$. 
lish procedures, including a role for the Congress, by which federal laws can be repealed. ${ }^{83}$ In determining how a self-executing treaty ought to be terminated, these procedures should be respected.

There are at least two reasons for giving weight to such procedures. First, as noted earlier, both self-executing treaties and federal statutes are classified as the "Law of the Land" by the Constitution. ${ }^{84}$ Similarly, termination of a self-executing treaty and repeal of a federal statute have identical domestic legal effects. Thus, at least as an initial matter, it would seem logical to treat one type of "Law of the Land" (self-executing treaties) in the same manner that other types of "Law of the Land" (federal statutes) are treated.

Second, many of the policy considerations that led the Framers to require, and subsequent generations to affirm, legislative participation in the repeal of federal statutes apply with equal force to the termination of self-executing treaties. Termination of a selfexecuting treaty directly alters existing private legal rights. ${ }^{85}$ Such an alteration may affect a number of groups whose interests conflict with one another. ${ }^{s 6}$ It is precisely this situation, where numerous competing interests are involved, that is best resolved by a democratic legislative process. ${ }^{87}$ In the words of James Madison, "The regulation of these various and interfering interests forms the principal task of modern legislation . . . " 88 Thus, the free-wheeling legislative compromise resulting from competition between numerous interests is accepted, in American political tradition, as the surest way to achieve fair and popularly accepted governmental decisions. ${ }^{89}$ Open public debate by elected representatives also

\$3 U.S. Const. art. I, $\$ 7$, cl. 2. United States v. Clarke (The Confiscation Cases), 87 U.S. (20 Wall.) $92,112-13$ (1874) ("No power was ever vested in the President to repeal an act of Congress.").

84 See note 75 supra \& accompanying text.

85 See notes 79-82 supra \& accompanying text.

86 For example, the termination of a self-executing tariff treaty would affect importers, exporters, consumers, labor, and competing industries, all in different ways. These groups might be expected to have sharply differing views regarding the desirability of terminating such a treaty.

$87 \mathrm{~A}$ number of commentators have viewed the legislative branch as a kind of marketplace in which representatives of different interest groups bargain for desired results. E.g., J. Buchanan, Freedom in Constitutional Contract (1977); J. Buchanan \& G. Tullock, The Calculus of Consent (1967); The Federalist No. 10 (J. Madison); Fiss, Foreword: The Forms of Justice, 93 Harv. L. Rev. 1, $9-11 \& n .25$ (1979).

$88 \mathrm{THE}$ FeDerarist No. 10, supra note 58, at 65 (J. Madison). Madison continued, "And what are the different classes of legislators but advocates and parties to the causes which they determine? ... [T]he most numerous party, or, in other words, the most powerful faction must be expected to prevail." Id.

89 See Freedman, Delegation of Power and Institutional Competence, $43 \mathrm{U}$. Crr. L. REv. 307 (1976). Dean Freedman argues for strict limits upon Con- 
contributes to popular acceptance of the legislature's actions. ${ }^{90}$ In short, Congress, as an institution, is more competent to resolve this type of problem than is the President. ${ }^{91}$

Thus a self-executing treaty, in both constitutional language and practical effect, is so similar to a federal statute that Congress. can claim a strong interest in participating in its termination.

\section{Non-Self-Executing Treaties}

Congress's interest in the termination of a non-self-executingtreaty is considerably weaker than the legislative interests implicated when a self-executing treaty is involved. A non-self-executing treaty contains only an agreement to undertake future action. In the words of the Supreme Court, it "import[s] a contract." 92 The Court has repeatedly and explicitly held that, unlike self-executing treaties, non-self-executing treaties do not create "Law of the Land." 93 Thus, a non-self-executing treaty does not create legally enforceable private rights or duties, ${ }^{94}$ does not supercede prior inconsistent federal law, ${ }^{95}$ and does not preempt state law..$^{96}$ Accordingly, termination of a non-self-executing treaty does not dissolve private legal rights or duties; if any such rights or obligations

gress's delegation of its taxation power, on the grounds that "no other institution of the federal government except Congress possesses the unique characteristics that the Framers relied upon to provide citizens with an institutional security against unfair or oppressive taxation ...." Id. 326.

90 The public acceptance, or "legitimacy," of a governmental institution is closely related to the ability of that institution to perform its functions successfully. J. Freedman, Crists and Legitmacacy 10 (1978) (citing M. Weber, The Theort of Social and Economic Organization 130-32 (T. Parsons ed. 1947)). Alexander Hamilton made this point while defending the Senate's control of the impeachment process. Thus, the Senate alone "would possess the degree of credit and authority, which might, on certain occasions, be indispensable towards reconciling the people to a decision ..." ThE FEDERALIST No. 65, supra note 58, at 19 (A. Hamilton).

91 Dean Freedman advanced the concept of "institutional competence" in the context of the delegation of governmental powers. Freedman, supra note 89, at 317-29. The notion is also applicable here: the external pressures upon the Congress, as well as its composition and internal mechanisms, strongly suggest that it will reach fairer, more popularly acceptable (if not more efficient) results than would the executive. See Cutler \& Johnson, Regulation and the Political Process, 84 Y ALE L.J. 1395, 1411-12 (1975).

92 Foster, 27 U.S. at 314. See text accompanying note 77 supra.

93 Foster, 27 U.S. at 314 . See note 75 supra.

94 Sei Fujii v. State, 38 Cal. 2d 718, 724, 242 P.2d 617, 622 (1952) (en banc) (The United Nations Charter, to which the United States is party, is not self-executing, and is therefore incapable of creating "justiciable rights in private persons immediately upon ratification.").

95 Foster, 27 U.S. at 314 ("the legislature must execute the contract before it can become a rule for the Court").

${ }^{96}$ Sei Fuiii, $38 \mathrm{Cal}, 2 \mathrm{~d}$ at 721,242 P.2d at 620. 
exist, they do so by virtue of federal statutes that implement the treaty and remain in force after its termination. ${ }^{27}$ Similarly, neither the making nor the dissolution of a non-self-executing treaty affects inconsistent federal statutes or state law.98 Consequently, few noteworthy domestic effects arise from the termination of a non-selfexecuting treaty.

Because the domestic effects of such a termination are so limited, there is little on which a legislative interest in participation in the termination decision can be predicated. If, in effect, little happens when the treaty is terminated, there appears to be no reason to override the President's interest in controlling the nation's international legal rights and obligations. ${ }^{99}$

\section{Subject Matter of the Treaty}

Another factor that affects the strength of the executive or legislative interest in the termination of a particular treaty is the subject matter of the treaty. The Constitution, and its historical and judicial glosses, establishes a comprehensive allocation of governmental powers between the executive and legislative branches. ${ }^{100}$ For example, Congress is granted broad control over foreign commerce, ${ }^{101}$ while the President is provided with considerable authority in military affairs. ${ }^{102}$ This constitutional framework, although often ambiguous, provides another focal point for defining the treaty termination power.

Given the silence of the Constitution and the ambiguity of historical practice ${ }^{103}$ on the treaty termination issue, one should be hesitant to define the power to terminate treaties in a way that would interfere with more clearly established allocations of power. Rather, the treaty termination power should be structured so as

97 I. Hensin, supra note 19, at 157 n.f ("Strictly, if a treaty is not selfexecuting it is not the treaty but the implementing legislation that is effectively law of the land." "). See also GWU Note, supra note 22 , at 311 n.48.

os See notes 94-96 supra \& accompanying text.

90 See text accompanying notes 65-72 supra.

100 For a rough outline of this framework, see Casper, supra note 44 , at 486-88, and Henkin, supra note 60.

101 U.S. Const. art. I, $\$ 8$, cl. 3 (Congress has power " $[t]$ o regulate Commerce with foreign Nations." See S. REP. No. 1298, 93d Cong., 2d Sess. 14, reprinted in [1974] U.S. CODE CONG. \& AD. News 7186, 7186 (noting Congress's special role in trade policy).

102 U.S. Const. art. II, $\$ 2$, cl. 1 ("The President shall be Commander in Chief of the Army and Navy of the United States . ..."). See A. SofaER, supra note 41 .

103 See note 21 supra. 
to conform to the existing constitutional framework of governmental powers, and to minimize the disruption of present institutional arrangements.

This approach to constitutional silence or uncertainty has been adopted in analogous contexts. For example, the Supreme Court has defined the President's power to remove government officers on the basis of the type of officer involved, ${ }^{104}$ seeking to preserve the existing constitutional separation of executive and legislative powers. ${ }^{105}$ Similarly, Congress's attempt to fashion a legislative veto ${ }^{106}$ over the exercise of delegated power has been examined on a case-by-case basis by the courts. ${ }^{107}$ Decisions have focused on the "disruption" of the existing division of governmental powers that various uses of the legislative veto create. ${ }^{108}$ Thus, Justice White has suggested that legislative vetoes in areas such as law enforcement and presidential appointments would be more objectionable than those in more "legislative" areas. ${ }^{109}$ This type of analysis, which attempts to conform an undefined governmental power to existing institutional relationships, is equally valid in the treaty termination context.

Two hypothetical treaties usefully illustrate this proposition. First, consider a treaty regulating foreign commerce-an agreement granting preferential tariff treatment to the goods of another nation, for example.110 Unilateral presidential termination of such a treaty would thrust the executive branch into an area that the Con-

$10 \pm$ Wiener v. United States, 357 U.S. 349 (1958); Humphrey's Executor v. United States, 295 U.S. 602 (1935).

105 L. TruBe, supra note 44 , at 188 \& n.14.

106 Legislative vetoes purport to allow Congress (or one house or committee) to disapprove of executive or agency action without being subject to a possible presidential veto. See generally Bruff \& Gellhorn, Congressional Control of Administrative Regulation: A Study of Legislative Vetoes, 90 HARv. L. REv. 1369 (1977); McGowan, Congress, Court, and Control of Delegated Power, 77 Couvm. L. REv. 1119 (1977).

107 E.g., Chadha v. Immigration \& Naturalization Serv., 634 F.2d 408 (9th Cir. 1980); Atkins v. United States, 556 F.2d 1028 (Ct. Cl. 1977) (en banc) (per curiam).

108 Chadha, 634 F.2d at 425,429 (holding that the case involves a "one-house disapproval [that] disrupts an essential function" of both the judicial and executive branches); Atkins, 556 F.2d at 1062-63 (one-house veto permissible when "status quo" not altered).

109 Buckley v. Valeo, 424 U.S. 1, 285-86 (1976) (White, J., concurring and dissenting). Judge Leventhal has also distinguished between legislative vetoes in cases involving "what is in substance legislative power" and those involving executive powers. Clark v. Valeo, 559 F.2d 642, 664 n.13 (D.C. Cir. 1977) (Leventhal, J., concurring).

110 E.g., Treaty of Friendship, Commerce and Navigation between the United States and Ireland, Sept. 14, 1950, 1 U.S.T. 788, T.I.A.S. No. 2155. 
stitution expressly commits to legislative control, ${ }^{111}$ and that Congress has taken special efforts to regulate. ${ }^{112}$ Termination of the treaty by the President acting alone would cut across Congress's efforts to regulate international trade. The resulting disruption would provide strong support for legislative claims to participation in the decision to terminate the hypothetical tariff treaty.

In contrast, consider a treaty dealing with military matters, such as an agreement to restrict the use of various types of weapons. ${ }^{113}$ The President, as Commander in Chief, ordinarily possesses broad authority over the nation's choice of military armaments. ${ }^{114}$ Subject to the broad limits of the appropriations process, the President may deploy military weaponry as he deems appropriate. Unilateral executive control over termination of a treaty dealing with military weaponry would not thrust the President into an area, such as foreign trade, regulated primarily by Congress. Indeed, requiring congressional participation in the termination of such treaties would interfere with the established powers of the executive branch. Congressional failure to approve termination of such a treaty could require the President to forego the use of weapons he thought necessary, or, alternatively, to violate the nation's treaty obligations. Absent a clear constitutional basis for such a view of the treaty termination power, this type of disruption should be avoided.

There may also be policy considerations, relating to the institutional competence of a particular branch, that suggest which branch or branches should terminate a treaty. For example, the President possesses a strong interest in unilaterally terminating most

111 See note 101 supra \& accompanying text.

112 See S. REP. No. 1298, supra note 101, at 14. In recent years, Congress has established a number of complex institutional arrangements requiring legislative participation in the formulation of international trade policy. For example, recent legislation establishes complicated procedures that the President must follow in negotiating and entering into international trade agreements. Trade Act of 1974, Pub. L. No. 93-618, 88 Stat. 1978 (codified at 19 U.S.C. $\$ \$ 2101-2487$ (1976)). See J. Jackson, International Economic Relations 128-30, 154-66, 816-24 (1977) (describing the Trade Act's attempts to curb executive discretion). For a collection of the numerous statutes that regulate foreign commerce, see sources cited in J. JACrson, supra, at 154 n.19.

113 E.g., Geneva Gas Protocol, June 17, 1925, 26 U.S.T. 57I, T.I.A.S. No. 8061; Biological Weapons Convention, Apr. 10, 1972, 26 U.S.T. 583, T.I.A.S. No. 8062; Treaty Between the United States and the Soviet Union on the Limitation of Anti-Ballistic Missile Systems, May 26, 1972, 23 U.S.T. 3435, T.I.A.S. No. 7503.

114 See note 102 supra. Even before the gradual accumulation of presidential power as Commander in Chief during the 1900s, it was recognized that the executive's authority extended to "the command of the forces and the conduct of campaigns." Ex Parte Milligan, 71 U.S. (4 Wall.) 2, 139 (1866) (Chase, C.J., concurring). 
military treaties. Military affairs frequently demand unique treatment; ${ }^{115}$ secrecy, centralized decision-making, speed, and consistency are of unusual importance in this area.110 These requirements are, in large part, incompatible with the open, decentralized, frequently slow-moving give-and-take of a representative legislature. ${ }^{117}$ In contrast, the executive branch possesses most, if not all, of the qualities necessary for efficient and successful military decision-making. 118 Consequently, despite our ordinary preference for the public debate and political compromise of the legislative branch, ${ }^{119}$ there might be persuasive reasons for permitting the President to unilaterally terminate a primarily military treaty.

Conversely, there would be strong policy justifications for requiring legislative participation in the decision to terminate a treaty dealing with foreign trade. The regulation of foreign commerce requires reconciliation of the interests of numerous groups including consumers, producers, laborers, shippers, and suppliers. This is precisely the situation that the American political tradition has placed within the legislature's control. ${ }^{120}$ Elected representatives, responsive to various interest groups and to popular opinion, as well as the give-and-take of the legislative process, have long been accepted as the wisest way to reconcile such competing social and economic interests.

\section{The Fundamental Character of the Treaty}

Another variable that bears upon the issue of which branch may terminate a treaty is the importance of the treaty in the context of the nation's foreign policy. It is difficult to enunciate a precise standard for measuring the "fundamentalness" of a treaty. There are, however, treaties that clearly are extraordinarily important in defining the position and attitude of the United States in world affairs-the North Atlantic Treaty, ${ }^{121}$ the United Nations

$115 \mathrm{~J}$. BuRns, supra note 61, at 208; I. DEstLER, supra note 46, at 6 ("When one reaches the political-military sphere, however, the case for ... [decentralized decision-making] becomes weaker, and the need for central control more urgent."); W. Erirotr, supra note 61 , at 66 .

116 See note 58 supra.

117 See text accompanying note 60 supra.

118 See text accompanying notes 58-59 supra.

119 See R. Luce, Legislative Procedure 2 (1922); Katzenbach, supra note 63.

120 See notes 85-91 supra \& accompanying text.

121 North Atlantic Treaty, April 4, 1949, 63 Stat. 2241, T.I.A.S. No. 1964. 
Charter, ${ }^{122}$ and the Strategic Arms Limitation Treaty, ${ }^{123}$ for example. These "fundamental" treaties lay the foundation for most of American foreign relations, and their termination would radically alter both the course of U.S. foreign policy and the place of the nation in world affairs. Exclusion of the legislature from such decision-making would severely curtail the congressional role in foreign relations.

Although there is virtually no agreement on the scope of the legislature's foreign relations power, ${ }^{124}$ few would deny that the legislative branch has some role in foreign affairs. ${ }^{125}$ If the executive possessed the power to unilaterally terminate "fundamental" treaties, it would be hard to avoid the conclusion that the legislature's foreign affairs power, no matter how narrowly it might be defined, had been unduly compromised. Although there is likely to be considerable difference of opinion as to the "fundamentalness" of particular treaties, the importance of a treaty termination should be considered in determining whether legislative participation in the termination should be required.

\section{A Proposed Balancing Test and Its Application}

The preceding section has set forth several presidential or congressional interests that may be implicated by the termination of any particular treaty. The strength, and even the existence, of these interests in termination will vary from treaty to treaty. A sensible approach to the termination of treaties would recognize and take into account these competing interests: the difficulty lies in finding a workable test that will accomplish this accommodation.

122 United Nations Charter, June 26, 1945, 59 Stat. 1031, T.S. No. 993. See Jankowitsch, The Utility of the United Nations System, $10 \mathrm{~J}$. INT'L L. \& Econ. 689 (1975); Sohn, The Shaping of International Law, 8 GA. J. INT'L \& CoMP. L. 1, 2 (1978).

123 Treaty Between the United States and the Soviet Union on the Limitation of Anti-Ballistic Missile Systems, May 26, 1972, 23 U.S.T. 3435, T.I.A.S. No. 7503. That this treaty is "fundamental" does not necessarily mean that the President could not terminate it unilaterally. For example, it is a military treaty, see text accompanying notes 113-14 supra, and that would have to be considered in the balancing test proposed by this Comment.

124 L. HENKan, supra note 19 , at 76 ("No one knows the reaches of the Foreign Affairs Power of Congress."). See generally id. 84-86.

125 Eleven of article I, section 8 's enumerated powers relate to international affairs in some way. L. Trme, supra note 44, at 275 . These, and Congress's "unenumerated foreign affairs power," L. Henkr,, supra note 19, at 68 , suggest a far from insignificant role for Congress in foreign affairs. Nonetheless, as noted above, see text accompanying notes 37-64 supra, the President has successfully asserted, and commentators have generally approved, extremely broad powers in the field. 
Considerable criticism has been directed at balancing tests as a solution to legal problems. ${ }^{126}$ This criticism is particularly appropriate when the interests being balanced are both imprecise and of widely differing character. Nonetheless, the usefulness of balancing tests in providing flexibility and in integrating a number of competing considerations is undeniable. ${ }^{12 t}$ Consequently, despite the general criticism these tests have received, a balancing test seems well-suited to dealing with the numerous competing governmental interests and political concerns implicated by particular treaty terminations. Indeed, it is difficult to posit an alternative test that could reconcile these various interests.

Undoubtedly, many difficult cases will arise, implicating significant legislative interests and political concerns against the substantial executive foreign affairs power, and perhaps against other executive interests as well. ${ }^{128}$ The resolution of these cases might occasionally appear to be ad hoc, resting more upon one's political sympathies than upon a careful weighing of interests. As discussed below, however, few arguments based upon separation of powers principles will be entirely convincing. ${ }^{129}$ The dispute and ambiguity underlying the subject make it difficult to attain consistently

126 Justice Black's opposition to balancing tests was well-known. E.g., City of El Paso v. Simmons, 379 U.S. 497, 528-33 (1965) (Black, J., dissenting); Communist Party v. Subversive Activities Control Bd., 367 U.S. 1, 164-67 (1961) (Black, J., dissenting). See Henkin, Infallibility Under Law: Constitutional Balancing, 78 Colum. L. REv. 1022, 1047 (1978); Leedes, The Supreme Court Mess, 57 TEx. L. REv. 1361, 1415-21 (1979). Cf. Authorities cited at L. TruBe, supra note 44 , at 582-84 \& nn.19-27 (first amendment balancing controversy).

${ }^{127} \mathrm{See}$ L. Trube, supra note 44, at 583 ("First, the "balancers" [in first amendment analysis] are right in concluding that it is impossible to escape the task of weighing the competing considerations.").

128 One such executive interest might arise from a lack of any congressional opposition to unilateral presidential termination of a treaty. Justice Jackson's concurrence in Youngstown Sheet \& Tube Co. v. Sawyer, 343 U.S. 579, 635-38 (1952), has frequently been cited for its theory of "fluctuating" presidential powers. E.g., Bruff, Presidential Power and Administrative Rulemaking, 88 YALE L.J. 451, 472-74 (1979). Jackson reasoned that (1) executive powers are at their height when "the President acts pursuant to an express or implied authorization of Congress," 343 U.S. at 635 ; (2) presidential powers are more limited, and vary according to "the imperatives of events and contemporary imponderables," id. 637, when Congress has neither approved nor disapproved of his action, and (3) the executive's powers are at their "lowest ebb" when the President "takes measures incompatible with the express or implied will of Congress." Id. Of course, if Congress has explicitly approved of the termination of a treaty, there will be no treaty termination dispute. If Congress, however, has remained silent, or spoken only indirectly, a claim that unilateral presidential termination was authorized by legislative action becomes far less persuasive. Nonetheless, consideration of the second branch in Jackson's tripartite model would suggest an executive "interest" of sorts in such cases. This would be particularly true where strong evidence of implied legislative approval exists.

120 See notes $178-79$ infra \& accompanying text. 
persuasive results. Thus, although the proposed balancing test may occasionally appear ad hoc or subjective, it is unlikely that any alternatives could avoid this shortcoming. In sum, because of its flexibility and capacity to isolate the numerous governmental interestis and political concerns implicated by treaty terminations, the proposed balancing test seems to be the best response to the treaty termination problem.

\section{A. Two Easy Cases}

The foregoing analysis of treaty termination and the proposed balancing test are usefully illustrated by two hypotheticals. The first example assumes unilateral executive termination of the Warsaw Convention, ${ }^{130}$ and the second posits a similar termination of the Arbitration Treaty between Denmark and the United States. ${ }^{131}$ The Warsaw Convention "was negotiated in 1929 and is today one of the principal multilateral agreements applicable to international transportation. It establishes uniformity of documentation and creates a uniform body of law with regard to the rights and responsibilities of passengers, shippers, and air carriers in international air transportation." 132 The convention is a self-executing treaty; thus, it creates enforceable legal rights and obligations in exactly the same manner that a federal statute does. ${ }^{133}$ For example, the convention creates a cause of action for those involved in international air accidents. ${ }^{134}$ Similarly, the treaty provides a two-year statute of limitations for certain claims, ${ }^{135}$ and establishes a variety of evidentiary

130 Convention for the Unification of Certain Rules Relating to International Transportation by Air, Oct. 12, 1929, 49 Stat. 3000, T.S. No. 876 [hereinafter cited as Warsaw Convention].

131 Arbitration Treaty, June 14, 1928, United States-Denmark, 46 Stat. 2265, T.S. No. 784 [hereinafter cited as Arbitration Treaty].

132 Dep't of State, Untted States Governarent Action Concerning the Warsatw Convention (1966), reprinted in 32 J. AmR L. \& Com. 243 (1966). See generally Lowenfeld \& Mendelsohn, The United States and the Warsaw Convention, 80 Hapv. L. REv. 497 (1967).

133 Benjamins v. British European Airways, 572 F.2d 913, 916-19 (2d Cir. 1978), cert. denied, 439 U.S. 1114 (1979) (Warsaw Convention creates a private right of action); Deutsche Lufthansa Aktiengesellschaft v. CAB, 479 F.2d 912,916 n.7 (D.C. Cir. 1973) ("The Convention itself is self-executing ... ."); Smith v. Canadian Pacific Airways, Ltd., 452 F.2d 798, 801-02 (2d Cir. 1971). See Calkins, The Cause of Action Under the Warsaw Convention, 26 J. Arr L. \& Cos. 217, 218 (1959) ("[T]he author is convinced that the draftsmen of the Convention intended to create a right of action based on the contract of carriage; . . . that [the Convention] is self-executing; and therefore the supreme law of the land."). See notes 78-79 supra \& accompanying text.

134 E.g., Benjamins, 572 F.2d at 916-19; Calkins, supra note 133, at 218.

185 Warsaw Convention, supra note 130, art. 29. 
presumptions applicable to passenger and shipper damage claims. ${ }^{136}$ Finally, the treaty places several limits on air carrier liability. ${ }^{137}$ Termination of the convention would dissolve this legal framework, generally replacing it with state law that would resolve issues differently than the treaty does. ${ }^{138}$

This type of change in the actual laws of the land should require participation by the legislature. Congress traditionally has played a major role in altering private legal rights, and its participation in this process has been considered of fundamental importance to the American political system. ${ }^{139}$ This role suggests that legislative participation in termination of the Warsaw Convention should be required.

It is no answer to argue that Congress is free to enact legislation that would recreate the legal framework of the convention. This would require the affirmative action of Congress, which might easily be frustrated, either intentionally ${ }^{140}$ or otherwise. ${ }^{141}$ The Warsaw Convention-containing a complicated web of legal requirements-would be particularly difficult to reenact. ${ }^{142}$ In addition, Congress's reenactment might well face a presidential veto. If the executive branch found the terms of the treaty objectionable, it might well be disposed similarly toward identical legislation. As a result of these obstacles to congressional reenactment of the treaty's legal provisions, the President's unilateral termination would have a long-lasting, as well as a direct, effect upon domestic legal rights.

Two other aspects of the convention are important. First, it deals with the subject of foreign commerce, an area specifically granted by the Constitution to Congress's control. ${ }^{143}$ Absent con-

136 Id. arts. 11, 26.

137 Id. arts. 3, 4, $12 \& 17-25$.

138 See Riggs, supra note 22, at 533.

139 See text accompanying notes 85-9I supra.

140 Commentators have frequently pointed out the extent to which minority interest groups may block legislative programs. E.g., Choper, The Supreme Court and the Political Branches: Democratic Theory and Practice, 122 U. PA. L. Rev. $810,817,821-30$ (1974) ("The most serious antimajoritarian forces in the congressional system are ... found ... in the structure and inner workings of the legislative process itself."). Thus, the enactment of legislation re-creating the Warsaw Convention might well be blocked during the legislative process.

141 Congress might simply neglect to enact the requisite legislation, deeming other duties more pressing. Similarly, disagreement over the precise form and contents of the legislation might block its passage.

142 The great number and complexity of the legal provisions of the Convention would increase the likelihood of congressional disagreement, and therefore impede passage of legislation re-creating these provisions.

143 See note 101 supra \& accompanying text. 
stitutional language relevant to treaty termination, this express grant should be important in determining how authority over foreign commerce ought to be divided between Congress and the President, even if such control is exercised by way of a treaty termination. Second, the treaty, although not "fundamental" to American foreign policy, ${ }^{144}$ is of considerable importance to international transportation. Thus, although clearly not analogous to termination of the North Atlantic Treaty, termination of the Warsaw Convention would have more than a de minimis impact on Congress's ability to participate in the formulation of foreign policy. Balancing these interests against the President's interest in controlling the nation's international obligations is, of course, difficult. Nonetheless, the weighty legislative interests at stake in this hypothetical strongly suggest that Congress should take part in the decision to terminate the Warsaw Convention. ${ }^{145}$

This can be contrasted with termination of the Arbitration Treaty between the United States and Denmark. The principal provision of this treaty states that "[a]ll differences relating to international matters in which the ... [parties] are concerned" 146 shall be submitted to a "competent tribunal" 147 for arbitration. The treaty also contains certain exceptions to this general requirement that international disputes be arbitrated. ${ }^{148}$

There is little, if any, basis for asserting a congressional interest in participating in termination of the Arbitration Treaty. The treaty is clearly non-self-executing: it creates no legal rights enforceable in U.S. courts and requires future governmental actions

144 See text accompanying notes 121-23 supra.

145 The United States, in fact, has taken major steps towards withdrawal from the Warsaw Convention in the past. In 1965, the President, through the State Department, delivered notice of U.S. withdrawal from the convention. 53 DEP'T Srate Bulc. 923, 923-24 (1965). The decision to withdraw was made without formal approval from Congress or the Senate. Riggs, supra note 22, at 526-27 \& n.5. See Kreindler, The Denunciation of the Warsaw Convention, 31 J. Am L. \& CoM. 291 (1965). There was, however, prior informal indication of Senate approval for the President's action. Riggs, supra note 22, at 527 n.5 (quoting Senate Foreign Relations Committee report: if legislation regarding liability insurance "is not enacted within a reasonable time ... the Department of State should take immediate steps to denounce the Warsaw Convention ....").

The withdrawal notice was intended as a negotiation tactic to win higher air carrier liability limits. Arguably, a requirement of congressional participation in the termination decision would unduly hinder the use of such tactics. It is equally likely, however, that congressional participation would enhance the U.S. bargaining position, by indicating a stronger national commitment. If flexibility were deemed essential, the legislature could delegate power to terminate the treaty to the President.

146 Arbitration Treaty, supra note 131, art. I.

$147 \mathrm{Id}$.

148 Id. art. II. 
if it is to be fulfilled. ${ }^{149}$ Consequently, termination of the treaty would not involve repealing the "Law of the Land," and would do nothing to alter the legal rights of litigants in domestic courts.

In addition, the treaty deals with a subject-the disposition of the nation's claims under international law-that the President has long exclusively controlled.150 Termination of the treaty, unlike the hypothetical termination of the Warsaw Convention, would not thrust the President into an area that Congress ordinarily regulates. Finally, the Arbitration Treaty is far from fundamental. It apparently has never been used, ${ }^{151}$ and its importance has been reduced by the establishment of the International Court of Justice. ${ }^{152}$ The treaty's termination would have little, if any, impact upon Congress's ability to participate in making foreign policy.

As this discussion suggests, an application of the proposed balancing test reveals little basis for congressional participation in termination of the Arbitration Treaty. The treaty's termination would have no effect on domestic law; it would involve a subject generally under exclusive executive control, and it would have little impact on Congress's ability to make foreign policy. Given this, unilateral executive termination of the Arbitration Treaty appears entirely appropriate.

\section{B. Termination of the Mutual Defense Treaty: $A$ Difficult Case}

An excellent example of a difficult case under the proposed balancing test is the Mutual Defense Treaty with Taiwan-the agreement that focused attention on the treaty termination issue. ${ }^{153}$ The principal substantive provision of the treaty states that "[e]ach Party recognizes that an armed attack in the West Pacific Area directed against the territories of either of the Parties would be dangerous to its own peace and safety and declares that it would act to meet the common danger in accordance with its constitutional processes." 154 Plainly, the provision contemplates only future governmental action. Each party to the treaty "declares" that, if specified events occur, it will act "in accordance with its constitutional processes" to respond. Thus, the treaty "import[s] a contract," and

149 See text accompanying notes $92-98$ supra.

150 See note 70 supra.

161 Personal interview with officials at the Department of State, Apr. 19, 1981. 152 But see N. LEECH, supra note 32, at 80-82 (arguing that arbitration has remained important despite existence of International Court of Justice).

${ }^{153}$ See notes I-5 supra \& accompanying text.

154 Mutual Defense Treaty, supra note 1, art. V. 
should be regarded as non-self-executing. ${ }^{155}$ Termination of the treaty, therefore, would not affect either the legal rights of U.S. citizens or the "Law of the Land."

Turning to the subject matter of the treaty, the character of the commitment made in the principal provision of the treaty is ambiguous. Either a declaration of war by Congress or the use of armed forces abroad by the President without a declaration of war would constitute action "in accordance with . . . [U.S.] constitutional processes." It is therefore unclear whether the action contemplated by, and thus the subject matter of, the Mutual Defense Treaty was based upon the President's authority as Commander in Chief of the armed forces or upon the power of Congress to declare war. ${ }^{168}$

In addition to this ambiguity of the treaty provision, the underlying subject-the use of armed forces abroad-is a matter of considerable dispute. ${ }^{157}$ The legislative and executive branches have long contested the constitutional authority of the President to em. ploy military forces abroad in the absence of a declaration of war or other legislative approval. The issue, as yet unresolved by either the judiciary or the commentators, ${ }^{158}$ seems likely to remain unsettled for some time. ${ }^{159}$ Consequently, the legislature cannot claim

155 The district court in Goldwater argued that many provisions in the Mutual Defense Treaty, including article V, were self-executing. Goldwater v. Carter, 481 F. Supp. $949,962-63$ \& n.60 (D.D.C.), rev'd per curiam, 617 F.2d 697 (D.C. Cir.) (en banc), vacated and remanded with directions to dismiss, 444 U.S. 996 (1979). This position was clearly erroneous. See L. HenkrN, supra note 19, at 160 \& n.100; N. LEECH, supra note 32 , at 929 ; L. TRIBE, supra note 44 , at $175 \mathrm{n} .14$ ("As a rule, [collective defense] treaties do not appear to be self-executing."). To reiterate Chief Justice Marshall's classic test, "when the terms of the stipulation import a contract, when either of the parties engages to perform a particular act, the treaty addresses itself to the political, not the judicial department; and the legislature must execute the contract, before it can become a rule for the Court." Foster v. Neilson, 27 U.S. (2 Pet.) 253, 314 (1829) (emphasis added). Plainly, a declaration to defend an ally at some future date is an engagement "to perform a particular act," and not a law addressed to the judiciary for enforcement. 106 Compare U.S. ConST. art. II, $\$ 2$, cl. 1 with id. att. I, $\$ 8$, cl. 11. case").

167 See L. Trmse, supra note 44, at 173 (noting "meager elucidation in the

158 Courts have frequently refused to address the legality of executive use of force abroad, E.g., Holtzman v. Schlesinger, 414 U.S. 1304 (Marshall, Circuit Justice, 1973); DaCosta v. Laird, 405 U.S. 979 (1972) (denial of certiorari); Massachusetts v. Laird, 400 U.S. 886 (1970) (denial of leave to file bill of complaint); Velvel v. Nixon, 396 U.S. 1042 (1970) (denial of certiorari); McArthur v. Clifford, 393 U.S. 1002 (1968) (denial of certiorari); Holmes v. United States, 391 U.S. 936 (1968) (denial of certiorari); Mora v. McNamara, 387 F.2d 862 (D.C. Cir.), cert. denied, 389 U.S. 934 (1967). See A. D'Amato \& R. O'Nex, THE JUdiciany AND VIETNAM 51-58 (1972); Henkin, Viet-Nam in the Courts of the United States: "Political Questions", 63 Am. J. INT'r L. 284 (1969). See also Casper, supra note 44.

109 Dean Casper has suggested that resolution, or rationalization, of the conflicts between the executive and legislature can only be attained if Congress enacts 
primary control over the subject of the treaty, as could be done, for example, in the case of a tariff treaty. ${ }^{100}$ Indeed, if anything, it is the President whose claims have been most widely accepted.161 Similarly, historical precedent weighs against legislative control over decisions to use armed forces abroad. ${ }^{162}$ Whatever one's view of their constitutional authority, it cannot be denied that Presidents have frequently employed the nation's military strength abroad without prior approval from the legislature.163 Lastly, several considerations of policy support executive control over this type of treaty termination. As noted above, unlike many matters involving economic regulation or individual rights, where openness and popular representation should seldom be dispensed with, subjects involving the military frequently require secrecy, unified decision-making, and speed. ${ }^{164}$ Thus, there would be good reason to allow the President to terminate unilaterally the Mutual Defense Treaty: the executive branch is better qualified to make the type of military decision upon which treaty termination is likely to be based.

Admittedly, the justifications for plenary executive power over termination of the Mutual Defense Treaty are subject to some dispute. The decision to terminate the Taiwan treaty involved both

"framework legislation," such as the War Powers Resolution. See note 44 supra. Such legislation would serve to define the responsibilities and duties of the President and Congress in areas now in dispute. Casper, supra note 44.

160 See text accompanying notes 110-12 supra.

161 E.g., L. Koent, The Presmenct and The Crusis 46 (1944); A. Sofaen, supra note 41; Monaghan, supra note 21; Rostow, supra note 21. But see Malawer, The Vietnam War Under the Constitution: Legal Issues Involved in the United States Military Involvement in VietNam, 31 U. PrTT. L. Rev. 205 (1969); Velvel, The War in Vietnam: Unconstitutional, Justiciable, and Jurisdictionally Attackable, 16 U. KAN. L. REv. 449 (1968).

162 See War Powers Legislation: Hearings on S. 731, S.J. Res. 18 \& S.J. Res. 59 Before the Senate Comm. on Foreign Relations, 92d Cong., 1st Sess. 7-8, 352-58 (1972) (statements of Professor Commager and Senator Goldwater). See also Monaghan, supra note 21, at 31; Rostow, supra note 21, at 863-70.

163 "Since the Constitution was adopted there have been at least 125 instances in which the President has ordered the armed forces to take action or maintain positions abroad without obtaining prior Congressional authorization ...." OFFICE of the Legal Advisor, U.S. Dep't of State, The Legarity of United States Participation In The Defense of VIeT NaM, reprinted in 75 Yale L.J. 1085, $110 \mathrm{I}$ (1966). See Monaghan, supra note 21, at 31 .

164 For a blunt assessment of the relative strengths and weaknesses of the executive and legislative branches in military affairs, consider the following statement made in 1971 by Representative I. Mendel Rivers, then Chairman of the House Armed Services Committee: "I'd rather have one general who knows this [military] business than a hundred senators who don't." A. FRYE, A ResponsrbLE Congress: The Poritics of National Securiry 5 (1975); Casper, supra note 44, at 481 . 
military ${ }^{165}$ and non-military ${ }^{166}$ considerations. To the extent that broad foreign policy issues were involved, the need for speed and secrecy might be reduced, and the need for public debate and legislative participation increased. Nonetheless, qualities such as superior information-gathering capabilities and centralized decisionmaking are valuable in making long-term strategic decisions. ${ }^{107}$ Further, foreign nations may demand secrecy in certain types of negotiations. - In addition, termination of the Mutual Defense Treaty was prompted largely by military concerns. ${ }^{168}$ Thus, although perhaps not completely compelling, there are significant policy considerations weighing in favor of unilateral presidential termination of the Mutual Defense Treaty.

Termination of the Taiwan treaty arguably raised a final type of political concern. If the treaty were regarded as a sufficiently fundamental part of U.S. foreign policy, it could be argued that its termination would so alter the course of U.S. foreign affairs that the legislature's role in the area would be impermissibly compromised by unilateral executive termination. ${ }^{160}$ Undoubtedly, the Mutual Defense Treaty was a significant agreement. For nearly three decades it was the foundation of U.S. policy toward China. ${ }^{170}$ Yet, particularly after changes during the 1970 s in American attitudes toward the People's Republic of China, it would be an exaggeration to claim that termination of the Taiwan treaty so fundamentally and dramatically changed U.S. foreign relations that congressional

165 E.g., Normalization of Relations with the People's Republic of China: Practical Implications: Hearings Before the Subcomm. on Asian and Pacific Affairs of the House Comm. on International Relations, 95th Cong., 1st Sess. viii, xii-xvi, 7-13, 23-24, 24-42 (1977) (statements of A. Doak Barnett, Nathaniel B. Thayer, and Robert A. Scalapino) [hereinafter cited as Normalization Hearings].

166 Id. 247-320 (economic implications), 321-51 (political implications).

167 See generally M. Bundy, supta note 61 ; J. BuRns, supra note 61 ; I. DESTLER, supra note 46; W. ELLIOTT, supra note 61, at 67-113, 177-93; L. HENKIN, supra note 19, at 37-65; R. NEustaDT, supra note 61.

108 The Joint Communique on the Establishment of Diplomatic Relations Between the United States of America and the People's Republic of China, 1978 Pus. PAPERS 2264 (Dec. 15, 1978), highlighted the importance of the strategic and military considerations underlying the decision to "normalize" relations with the People's Republic. Thus, the communique proclaimed that both parties "wish to reduce the danger of international military conflict," and perhaps more importantly, that neither "should seek hegemony in the Asia-Pacific region ... . and [that] each is opposed to [the] efforts by any other country or group of countries to establish such hegemony." Id. It has been observed that "hegemony" is "a euphemism denoting the Soviet Union" in the diplomatic parlance of the People's Republic. Normalization Hearings, supra note 165, at xii. See id. 28-34 (statement of Robert A. Scalapino), 154-60 (statement of Donald S. Zagoria). See also Cohen, A China Policy for the Next Administration, 55 FOREIGN AFr. 20 (1976).

169 See text accompanying notes 121-25 supra.

170 See Normalization Hearings, supra note 165, at xi-xii, 160-68 (statement of Robert W. Barnett), 229 (statement of Hungdah Chiu). 
powers were unduly compromised. The role of the Mutual Defense Treaty in U.S. foreign affairs was in no way comparable to that of the North Atlantic Treaty Organization or the United Nations. The thaw in U.S. relations with the People's Republic greatly reduced the practical importance of the treaty; ${ }^{171}$ there came to be less to fear from the mainland. Similarly, growing Soviet power led to a shift in U.S. concerns. ${ }^{172}$ These, and other developments, ${ }^{173}$ support the conclusion that termination of the Mutual Defense Treaty was not so "fundamental" an event as to give rise to any compelling legislative interests in participation in the termination decision.

The termination of the Mutual Defense Treaty presents a difficult case, pitting several significant arguments for legislative participation against competing presidential claims. Nonetheless, this Comment takes the position that unilateral executive termination of the treaty was constitutionally permissible. The treaty's termination involved no repeal of the "Law of the Land" and did not threaten to disrupt settled legislative efforts. In addition, although the treaty was important, unilateral presidential termination did not leave Congress unable to participate in the formulation of the nation's foreign policy. Consequently, the President's unilateral decision to terminate implicated few of the legislative interests that would be present, for example, if the Warsaw Convention were terminated. Conversely, the President possessed significant claims to control over the nation's military affairs and its international commitments. Thus, while the conclusion is open to legitimate dispute, the executive's interests in power to unilaterally terminate the Mutual Defense Treaty appear to outweigh Congress's interests in participating in the decision.

\section{A Suggested Procedure for Determining Who May TERMinate a Treaty}

\section{A. The Need for a Procedural Framework}

The decision to terminate the Mutual Defense Treaty with Taiwan apparently was made by President Carter and members of his staff after little, if any, consultation with legislative representa-

171 Id. 239.

172 E.g., id. 160-68 (statement of Robert Barnett).

173 The awkwardness inherent in a U.S. refusal to recognize a government that controlled some 900 million citizens was frequently mentioned. E.g., id. 8 (statement of A. Doak Barnett), 208 (statement of Ray S. Cline). Similarly, the economic implications of normalization of relations with the People's Republic were an important consideration. E.g., id. 247-320. 
tives. ${ }^{174}$ Although a limited number of Senate leaders were informed of the decision shortly before it was made public, ${ }^{175}$ little attempt was made to hear opposition or win support in Congress. Indeed, the decision was cloaked in secrecy until its announcement. ${ }^{170}$ This approach to the treaty termination created widespread resentment among members of Congress. ${ }^{177}$ This section examines the process by which the decision how to terminate a treaty is made, and argues that a well-designed decision-making procedure will eliminate much of the conflict surrounding future treaty terminations.

Fundamental disagreement surrounds the theory (or theories) of the separation of powers.178 In the words of Louis Henkin,

174 Complaint for Declaratory and Injunctive Relief $\llbracket 28$, Goldwater v. Carter, 481 F. Supp. 949 (D.D.C. 1979), reprinted in Treaty Termination Hearings, supra note 21, at 560; N.Y. Times, Dec. 18, 1978, at A12, col. 1 ("An aura of secrecy surrounded the [normalization] negotiations."); N.Y. Times, Dec. 20, 1978, at A14, col. 4 (quoting President Carter: "in the last two or three weeks ... we did not consult with anyone outside of a very tiny group within the Executive Branch of Government ...."); Washington Post, Dec. 17, 1978, at A12, col. 1; Personal Interview with Douglas J. Bennet, Jr., Assistant Secretary for Congressional Relations, Jan. 19, 1981 (confirming absence of effective consultation with Congress) [hereinafter cited as Interview]. But see Declaration of Richard Holbrooke II Goldwater v. Carter, 481 F. Supp. 949 (D.D.C. 1979), reprinted in Treaty Termination Hearings, supra note 21, at 85-86. See generally House Comm. on Foreign Affarrs, 96th Cong., 24 Sess., Executive-Legrstative Consultations on China Policy, 1978-79 (Comm. Print 1980) (criticizing absence of consultation in normalization and termination decisions) [hereinafter cited as CFINA PoLTCY].

For critical discussions of the Carter administration's handling of foreign affairs, particularly as regards consultation and coordination with the Congress, see generally Hoffmann, A View from At Home: The Perils of Incoherence, 57 Fonetgn AFF. 463 (1978); Yankelovich, Farewell to "President Knows Best", 57 Fonejgn Afr. 670 (1978). But see Bull, A View from Abroad: Consistency under Pressure, 57 Foreign AFr. 441 (1978).

175 N.Y. Times, Dec. 19, 1978, at A15, col. I (quoting Senator Javits' response to the question whether there had been "adequate" consultation with congressional leaders prior to termination of the Mutual Defense Treaty and de-recognition of Taiwan: "Obviously not."); Washington Post, Dec. 16, 1978, at A1, col. I (quoting Senator Glenn: "Calling a few of us in one hour before he goes on television doesn't seem like much consultation."); id. A12, col. 4 ("Congressional leaders were briefed on the decision ... [to de-recognize Taiwan and terminate the Mutual Defense Treaty] three hours before the televised speech."). See generally Chind Polrox, supra note 174, at 3-5.

176 See note 174 supra. See generally Canna PoLrcy, supra note 174, at 29-32.

177 N.Y. Times, Dec. 18, 1978, at A13, col. 1 ("the dramatic move by Mr. Carter to abrogate the Taiwan treaty at the end of 1979 has ruffled a number of Senators"); N.Y. Times, Dec. 20, 1978, at A11, col. 1 (report of Senator Helms' charge that administration deliberately misled Senate on the subject of normalization plans). See Cenna Pourcy, supra note 174, at 3-5.

178 See note 39 supra. See also W. Erurort, supra note 61, at 44 ("The Constitution did not define with precision the respective roles of the Congress and of the President in foreign policy."); Casper, 61 VA. L. REv. 777 (1975) (responding to Henkin, supra note 60) ("the great abstraction of separation of powers 
"Major struggles for power between the President and Congress, then, are about equally intractable under all theories of constitutional power in foreign affairs." ${ }^{179}$ As a result of this basic disagreement, many allocations of governmental authority based upon separation of powers principles, including those involving the treaty rermination power, will be open to powerful criticism..$^{180}$ Thus, it is particularly important that there exist a procedure for resolving treaty termination disputes in a manner acceptable to both the legislative and executive branches. If the legal and constitutional resolution of treaty termination disputes seldom will be clear-cut, the likelihood of conflict between the Congress and the President will be increased.181 Appeal to constitutional language, theory, and interpretation will seldom be persuasive. ${ }^{182}$ Instead, political considerations, personal predilections, and institutional loyalties will determine the actions of most participants in governmental disputes. ${ }^{183}$

Several commentators, responding to the vagueness of separation of powers principles, have urged that Congress enact legislation designed to define the respective spheres of executive and legislative power. ${ }^{184}$ Such "framework legislation" is intended to inject a degree of clarity and stability into governmental relations, by providing substantive guidelines and procedural mechanisms for resolving governmental disputes. ${ }^{185}$ The preceding sections attempted

is only valuable as a starting point in describing the respective roles of Congress and the President in formulating and implementing foreign policy").

179 L. HeNKrin, supra note 19, at 28.

180 See, e.g., Casper, supra note 44, at 482-83, 498 (discussing failures to "legitimate" national foreign policy in 1970s).

181 See $i d .468$ (noting tendency to employ "political means of "getting back" " at a President who had aroused congressional displeasure).

182 See id.

183 See id. 464-81; Henkin, supra note 60, at 754-57.

184 Balmer, supra note 49; Casper, supra note 44, at 481-82, 491-98; Barton, Book Review, 58 Tex. L. REv. 1015 (1980).

185 Dean Casper, discussing the importance of "framework legislation," see note 159 supra, made several points also applicable in this context:

Framework legislation thus forces both Congress and the President to focus on constitutional considerations, which are ordinarily submerged in disputes concerning specific policies. By providing institutionalized forms for consultation and the resolution of disagreements, it also gives greater specificity to the notion of legal constraints and attempts to stabilize to a greater extent expectations about the ways in which governmental power is exercised. Finally, by providing procedures for the evaluation and control of exercises of presidential power, it strives for constitutional legitimacy.

Casper, supra note 44 , at 482 (emphasis added). A properly designed procedure for deciding how to terminate a treaty would share many of these strengths, allow- 
to provide substantive guidelines for resolving treaty termination disputes. As has been recognized, however, procedural guidelines are equally important to the resolution of constitutional disputes between Congress and the President. ${ }^{186}$ Thus, one commentator has linked an effective foreign policy to "changes in organization and procedures both within the Executive and the Legislative Branches themselves and for the conduct of relations between them." 187 Congress, recognizing the strength of these observations, has enacted several important pieces of legislation requiring the President to meet certain procedural requirements (such as consulting with specified congressional committees) before exercising power delegated to him by the legislature. ${ }^{188}$ These kinds of procedural frameworks, aimed at reducing the ambiguity of the allocation of the foreign affairs power, have received widespread scholarly approval. ${ }^{189}$

Legislation is not, of course, the only means of establishing a procedural framework for the resolution of disputes concerning governmental powers. ${ }^{190}$ Either the development of informal governmental practices, or the promulgation of regulations by the President, could provide a basis for such a procedure. The important point is that a well-defined procedural framework for resolving treaty termination disputes might reduce both the frequency and the costs of such disputes.

\section{B. Objectives of a Procedural Framework}

In designing a procedure intended to reduce the ambiguity and potential for conflict created by treaty terminations, two con-

ing "focus on constitutional considerations," "providing institutionalized forms for consultations," and "striv[ing] for constitutional legitimacy."

Another commentator, discussing conditions included in foreign assistance legislation, applauded the procedural mechanisms established as a result of such developments. Balmer, supra note 49, at 236-38.

186 E.g., T. Franck \& E. Weisband, supra note 48, passim; Bennet, Congress in Foreign Policy: Who Needs 1t?, 57 ForeIGN AFF. 40, 45-49 (1978); Casper, supra note 44, at 481-82; Henkin, supra note 60, at 771-74; Rovine, Separation of Powers and International Executive Agreements, 52 IND. L.J. 397, 431 (1977). 187 Henkin, supra note 60 , at 771 .

188 E.g., Trade Agreements Act of 1979, Pub. L. No. 96-39, 93 Stat. 144 (to be codified in scattered sections of 19 U.S.C.); Foreign Assistance Act of 1961, Pub. L. No. 87-195, §502B, 75 Stat. 424 as amended by International Security Assistance and Arms Export Control Act of 1976, Pub. L. No. 94-329, $\$ 301,90$ Stat. 748 (codified at 22 U.S.C. $\$ 2304$ (1976)); Export Administration Act of 1979, Pub. L. No. 96-72, 93 Stat. 503 (to be codified in scattered sections of 50 U.S.C.).

189 E.g., Balmer, supra note 49; Casper, supra note 44; Henkin, supra note 60; Rovine, stpra note 186; Sparkman, supra note 49.

190 See Henkin, supra note 60, at 771-76; Rovine, supra note 186, at 431. 
siderations are important. First, the procedure should be unambiguously defined. Second, the procedure should maximize consultation with Congress, while safeguarding legitimate executive interests.

An unambiguous and predictable decision-making process would inject a much-needed element of certainty into an otherwise unclear area. ${ }^{191}$ Similarly, it would provide a forum, other than the courts, ${ }^{102}$ in which conflicting views might be advanced..$^{193}$ Finally, a clearly stated procedure would reduce ex post facto sparring between the executive and legislature as to what constitutes appropriate consultation. Much of the friction and antagonism that surrounded the Taiwan treaty termination may have resulted from the unorthodox and sudden character of the President's actions and from the uncertainty of Congress when faced with an unfamiliar problem. ${ }^{104}$ A clearly defined procedure would alleviate such problems and allow both the executive and the legislature to focus on the underlying issues presented in specific cases.

The importance of consultation between the legislature and executive has been emphasized frequently. Consultation is likely

191 See notes 178-79 supra \& accompanying text.

Commentators have frequently noted the importance of an established and consistent decision-making procedure in similar contexts. For example:

If the executive branch and Congress are able to agree on what consultation should involve, which members of Congress are to be consulted, and at what point in the decision-making process consultation ought to occur, the potential for conflict and confrontation between the two branches can be reduced and a better working relationship facilitated.

Hamilton \& Van Dusen, Making the Separation of Powers Work, 57 FonexGN AFr. 17, 33-34 (1978). See Bennet, supra note 186; Casper, supra note 44, at 482 (noting advantages of "institutionalized forms for consultation and the resolution of disagreements").

Thus, it was recently argued that:

Effective prior consultation, better information flow and education on the issues are the best available vehicles to lubricate the foreign policy process, reduce frictions and ensure that out of any foreign policy debate over what policy to pursue there emerges a coherent strategy that has been significantly strengthened by congressional participation.

Hamilton \& Van Dusen, supra, at 39.

192 It is unlikely, given the Goldwater case, that courts would resolve future treaty termination disputes. See notes 14-18 supra \& accompanying text. Thus, the existence of an alternative forum becomes all the more important. See Casper, supra note 44 , at $464-74$. at $28-29$.

193 See Casper, supra note 44, at 482; Hamilton \& Van Dusen, supra note 191,

194 See notes $174-78$ supra \& accompanying text.

One writer has speculated that the standard State Department procedure for entering treaties was used in deciding how to terminate the Taiwan treaty. VAND. Note, supra note 2, at 134 n.4. Officials at the State Department did not confirm this scenario. Interview, supra note 174. 
to increase the support, both political and popular, of the nation's foreign policy. It also tends to legitimate foreign policy positions by dispelling perceptions of presidential autocracy. ${ }^{195}$ Consultation may also increase the quality and effectiveness of the nation's foreign policy. Finally, consultation serves to restrain possible abuses of executive power. ${ }^{198}$ Although far from a panacea, ${ }^{197}$ consultation between the President and Congress seems likely to contribute to a more effective foreign policy.

It is important, however, that the procedures for consultation be designed to allow actual legislative contribution to the decisionmaking process. Thus, consultation should include a presentation of underlying information to legislative members and should allow opportunities for exploration of the issues raised by such information. ${ }^{198}$ Similarly, the consultation process should occur prior to the implementation of any decisions, and should be sufficiently flexible to permit alteration of executive plans as a result of legislative comments. ${ }^{199}$ Absent opportunity for effective congressional input, the consultation process would accomplish little and would quickly be perceived as a sham.

The consultation process should also be designed to preserve the institutional strengths that the executive branch brings to foreign policy decision-making-secrecy, speed, and consistency. ${ }^{200}$ Thus, commentators have urged that consultation focus upon selected members of the Congress, such as party leaders and committee chairmen. ${ }^{201}$ This approach would minimize information leaks, and the accompanying embarrassment to both the United States and foreign governments, and would allow relatively swift governmental decision-making. Although this approach plainly limits the scope of consultation, it appears necessary to avoid the costs of prior consultation with all 535 members of Congress.

195 E.g., Bennet, supra note 186; Casper, supra note 44; Chace, Is a Foreign Policy Consensus Possible? 57 ForeIgN AFF. I (1978); Hamilton \& Van Dusen, supra note 191; Katzenbach, supra note 63.

196 See authorities cited in note 195 supra.

197 See Cutler, To Form A Government, 59 FonEIGN AFF. 126, 138-39 (1980); Hamilton \& Van Dusen, supra note 191, at 35.

198 T. Franck \& E. WexsBand, supra note 48, at 227-57; Bennet, supra note 186, at 45-48; Hamilton \& Van Dusen, supra note 191, at 32-39.

199 See note 198 supra.

200 See text accompanying notes 115-16 supra.

201 E.g., T. FRANCK \& E. WEISBAND, supra note 48, at 210-26; Balmer, supra note 49; Franck, After the Fall: The New Procedural Framework for Congressional Control Over the War Power, 71 AM. J. INT'L L. 605, 624-25 (1977); Henkin, supra note 60, at 772-74; King \& Leavens, supra note 46, at 91. 


\section{Existing Models For Treaty Termination Procedure}

There is surprisingly direct precedential support for the creation of a procedural mechanism to resolve constitutional disputes involving treaties. Despite the lack of textual support in the Constitution, Presidents frequently have entered into agreements with foreign states without relying upon the treaty-making process. The President has made thousands of "sole executive agreements," without obtaining the approval of either the Senate or Congress. ${ }^{202}$ These agreements are justified as an exercise of the constitutional powers of the President, or as an exercise of power delegated to the executive by treaty or statute. ${ }^{203}$ Similarly, "congressional-executive agreements," approved by a majority of each house, frequently have been made. ${ }^{204}$ Both types of executive agreement have international effects identical to those of treaties: the nation is bound by international law to fulfill its obligations in good faith. ${ }^{205}$ Neither form of agreement, however, receives the two-thirds senatorial approval necessary to make a treaty. After considerable debate regarding their constitutional propriety, ${ }^{206}$ executive agreements have received general acceptance. ${ }^{207}$ Nonetheless, it was recognized that the use of such agreements raised important constitutional issues.

Concerns about the use of executive agreements reached a peak in the early 1970s. It was widely perceived in Congress that the President was using "sole executive agreements" both too frequently ${ }^{208}$ and for unduly important agreements. ${ }^{209}$ The executive

202 I D. O'Conneld, Internationad Law 206 (2d ed. 1970), reprinted in N. LEECH, supra note 32, at 1012-15; Rovine, supra note 186, at 397-99; Comment, Self-Executing Executive Agreements: A Separation of Powers Problem, 24 Bufralo L. Rev. 137 (1974) [hereinafter cited as BuFFalo Comment].

203 Rovine, supra note 186 , at $409-16$.

$204 \mathrm{D}$. O'CoNNeLI, supra note 202; Henkin, The Treaty Makers and the Law Makers: The Law of the Land and Foreign Relations, 107 U. PA. L. REv. 903 (1959). Slonim, Congressional-Executive Agreements, 14 Colum. J. 'Transnat'l L. 434 (1975).

205 See note 34 supra \& accompanying text.

206 See Borchard, Treaties and Executive Agreements-A Reply, 54 YaLE L.J. 616 (1945); McDougal \& Lans, supra note 21, at 534 (part II); Rovine, supra note 186; Bufraco Comment, supra note 202.

207 See Rovine, supra note 186, at 409-16.

208 Congressional Review of International Agreements: Hearings Before the Subcomm. on International Security and Scientific Affairs of the House Comm. on International Relations, 94th Cong., 2d Sess. 4 (1976) [hereinafter cited as Congressional Review Hearings].

As of January 1, 1972, the United States was party to 947 treaties and 4,359 executive agreements. T. FrancK \& E. WEIsBand, supra note 48 , at $144-45 \& \mathrm{n} .86$. See L. HENKIN, supra note 19, at 173 \& n.I (quoting Secretary of State Dulles: "every time we open a new privy, we have to have an executive agreement"); Rovine, supra note 186, at 398 n.6 (providing annual statistics for treaties and executive agreements).

209 See Congressional Review Hearings, supra note 208, at 4. 
branch responded to this criticism ${ }^{210}$ by clarifying the internal procedures that the State Department followed in selecting the appropriate form that international agreements would take.211 Two recent commentators characterized the internal procedures implemented by the State Department as a "felicitous move"; ${ }^{212}$ legislators generally have agreed. ${ }^{213}$ In light of their apparent initial success, the State Department guidelines deserve closer examination.

The State Department procedure is expressly designed to prevent "invasion or compromise" of legislative powers by the executive. ${ }^{214}$ Thus, if there is "any question whether an international agreement should be concluded as a treaty or as an international agreement other than a treaty, the matter is brought to the attention of the Legal Adviser. If the Legal Adviser considers the question to be a serious one that may warrant congressional consultation," further internal review is required.215 Finally, "[c]onsultations on such questions will be held with congressional leaders and com-

210 Congress considered a variety of legislation designed to regulate the use of executive agreements. See Rovine, supra note 186, at 399-401. The only such proposal to be enacted was the Case-Zablocki Act, requiring the Secretary of State to transmit the texts of all executive agreements entered into by the United States to Congress. Act of August 22, 1972, Pub. L. No. 92-403, 86 Stat. 619 (codified at 1 U.S.C. $\S 112 b(1976))$.

211 State Department Procedures on Treaties and Other International Agreements, Circular No. 175 (Oct. 25, 1974), 11 Foreign Affarrs Manual 700 [hereinafter cited as Treaty Procedure], reprinted in HOUSE CONOM. ON INTERNATronal Relations \& Senate Comm. on Foreign Relations, 95th Cong., 2d Sess., Legislation on Foreign Relations Through 1977 at 89 (Joint Comm. Print 1978) [hereinafter cited as Legislation on Foretgn Relations]. See T. Franch \& E. WetsBand, supra note 48, at 151 (quoting letter from Douglas J. Bennet, Jr., Assistant Secretary for Congressional Relations, to John Sparkman, Senate Foreign Relations Committee, reprinted in International Agreements Consultation Resolution, S. Rep. No. 1171, 95th Cong., 2d Sess. 3 (1978)).

The State Department procedure is binding on State Department officials, although it lacks the force of either law or a federal regulation. Rovine, supra note 186, at 417 n.105.

See also J. Boyd, Digest of United States Practice in Internationat Law 413 (1977); E. McDoweld, Digest of Unted States Practice in International LAW 294 (1975).

212 T. Franck \& E. WeISBAND, supta note 48, at 151 ("a felicitous move in reviving the Senate's advisory role"); see Rovine, supra note 186, at 406-21.

213 E.g., Letter from Senator John Sparkman, Chairman, Senate Foreign Relations Committee, to Douglas J. Bennet, Jr., Assistant Secretary for Congressional Relations, July 28, 1978, Washington, D.C., reprinted in S. REP. No. 1171, supra note 211 .

214 Treaty Procedure, supra note 211 , at 721.3 , reprinted in LegISLATION oN Foneign Retations, supta note 211, at 91 .

215 Treaty Procedure, supra note 211 , at 721.4 (b), reprinted in I.EGISLATION oN Foreign Rerations, supra note 211, at 91-92. The appropriate channels of internal review within the State Department are set forth. Id. 
mittees as may be appropriate." 216 This procedure, by providing for consultation and discussion with the legislative branch, has provided a useful approach to a difficult constitutional question that, like the treaty termination issue, has a high potential for executivelegislative dispute. Accordingly, it likely would provide a workable procedural framework for applying the substantive treaty termination guidelines suggested earlier.

Although the Department of State procedure provides a useful starting point for the development of a decision-making mechanism in the treaty termination context, it might be improved by certain changes. The requirement that a "serious question" exist before consultation with the legislature occurs seems, at least on its face, overly restrictive. Some lesser standard, less biased toward executive interests, would increase the opportunities for consultation with the legislature and decrease the likelihood of heavy-handed executive decision-making. Similarly, the proviso that consultation occur "as may be appropriate" should be reformulated. A narrow definition of those circumstances that will justify dispensing with consultation would provide a desirable check on unilateral executive actions, while legitimate executive interests could be articulated in the proviso. Finally, there should be some elaboration on the provision that "appropriate" congressional leaders and committees be "consulted." Although the precise types and manners of consultation are beyond the scope of this Comment, ${ }^{217}$ whatever procedure is chosen should be clearly defined. For example, the congressional leaders and committees who are to be consulted should be specified, while leaving the door open to more extensive consultations if necessary. ${ }^{218}$ Similarly, the manner of consultationformal briefing versus informal discussion-might be specified. Such provisions would guarantee a minimum level of discussion and information dissemination, and would make clear the fact that a forum for opposition to proposed executive actions is available.

In sum, the internal State Department procedure for determining how to enter into an international agreement provides a useful example in designing a procedure for deciding how to terminate a treaty. It easily could be adopted in conjunction with the balancing test suggested earlier. Neither the existing process of con-

216 Treaty Procedure, supra note 211 , at $721.4(c)$, reprinted in LEGisLation on Foreign Relations, supra note 211 , at 92.

217 For discussion of the advantages and disadvantages of different types of consultation, see generally I. DESTLER, supra note 46; Bennet, supra note 186; Hamilton \& Van Dusen, supra note 191, at 35-39.

218 See note 217 supra. 
sultation, nor the suggested changes, will prevent disputes. They may, however, contribute to a swifter, more efficient resolution of such conflicts by providing an element of certainty and a forum for exchanging views.

\section{Conclusion}

This Comment has addressed the question whether the termination of a treaty requires legislative participation, or, rather, only executive action. Observing that the United States is party to a wide variety of treaties, it suggests that different treaty terminations will implicate different congressional and presidential interests in controlling the termination decision. Depending on the interests implicated, unilateral presidential treaty termination will be permissible in some cases, while in others, legislative participation will be required. A balancing test, looking to the various governmental interests at stake in treaty terminations, was proposed for determining the appropriate manner of making a particular treaty termination decision. The Comment concluded by arguing that, whatever test may be adopted, an established procedure for deciding who is to participate in treaty terminations would be desirable. Relying on existing State Department practices, one possible procedure has been suggested. 